\section{A MULTIDISCIPLINARY RESEARCH PROGRAM \\ DIRECTED TOWARD UTILIZATION OF \\ SOLAR ENERGY THROUGH BIOCONVERSION \\ OF RENEWABLE RESOURCES \\ Progress Report}
William R. Finnerty, Project officer Office of Energy Research
Biological Sciences, Room 831
University of Georgia
Athens, Georgia 30602

This report was prepared as an account of work sponsored by the United States Government. Neither the United Statopment Administration, nor any of their employees, nor any of their makes any subcontractors, of their employess, mes any legal warranty, express or implied, or acsacy, completeness liability or responsibility for the accaparatus, product or or usefuiness of any in represents that its use would no process disclosed, owned rights.

July, 1976

\footnotetext{
PREPARED FOR THE

U.S. ENERGY RESEARCH AND DEVELOPMENT ADMINISTRATION

UNDER CONTRACT E (38-1)-888
}

\title{
MASTER
}




\section{DISCLAIMER}

This report was prepared as an account of work sponsored by an agency of the United States Government. Neither the United States Government nor any agency Thereof, nor any of their employees, makes any warranty, express or implied, or assumes any legal liability or responsibility for the accuracy, completeness, or usefulness of any information, apparatus, product, or process disclosed, or represents that its use would not infringe privately owned rights. Reference herein to any specific commercial product, process, or service by trade name, trademark, manufacturer, or otherwise does not necessarily constitute or imply its endorsement, recommendation, or favoring by the United States Government or any agency thereof. The views and opinions of authors expressed herein do not necessarily state or reflect those of the United States Government or any agency thereof. 


\section{DISCLAIMER}

Portions of this document may be illegible in electronic image products. Images are produced from the best available original document. 
PROGRESS REPORT CONTENTS

(SRO-888-1)

$\underline{\text { PAGE }}$

1. Disposition Document - 427

2. Progress Report (SRO-888-1)

a) Disclaimer Statement.................... 1

b) General Introduction to Progress Report......... 2

c) Abstract to Program A. Brown and Steinbeck...... 3

d) Program A Progress Report. Brown and Steinbeck.... 4

e) Abstract to Program B. Brown............. 10

f) Program B Progress Report. Brown........... 11

g) Abstract to Program C. Finnerty............. 14

h) Program C Progress Report. Finnerty.......... 15

i) Abstract to Program D. Peck and Ljungdahl....... 50

j) Program D Progress Report. Peck and Ljungdahl..... 51

k) Reprints
1) SRO-888-2 (3 copies)
2) $\mathrm{SRO}-888-3$ (3 copies)
3) $\mathrm{SRO}-888-4$ (3 copies)
4) SRO-888-5 (3 copies)
5) SRo-888-6 (3 copies)
6) SRO-888-7 (3 coples).
7) sko-888-8 (3 copies)
8) $\mathrm{SRO}-888-9$ (3 copies)
9) SRO-888-10 (3 copies)
10) SRo-888-11 (3 copies) 
This report was prepared as an account of work sponsored by the United States Government. Neither the United States nor the United States Energy Research and Development Administration, nor any of their employees, nor any of their contractors, subcontractors, or their employees, makes any warranty, express or implied, or assumes any legal liability or responsibility for the accuracy, completeness, or usefulness of any infor-. mation, apparatus, product or process disclosed, or represents that its use would not infringe privately-owned rights. 
The progress report has been divided into 4 sections as contained in the original proposal with each section prepared by the principal investigator. Also, each section contains an ABSTRACT preceding the main body of the report. A general abstract has been prepared for integrating all separate programs.

The progress of the research to date has generated the following number of total reports:

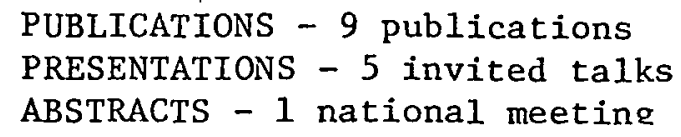

A number of manuscripts are currently in preparation for publication in scientific journals.

The multidisciplinary program has been considered a successful effort at the University of Georgia. A close degree of cooperation has resulted between the various projects wherein contributions and criticisms have proved invaluable in maintaining direction and purpose. The program has brought together a group of senior scientists from varying disciplines that normally do not interact at a scientific level. The interaction has proven to be mutually beneficial to the overall objectives of the program.

The following renewal proposal is submitted for consideration of continued funding with a detailed budget for the continuing year and projected second and third budgets, renewable annually. A three year approval of funding is requested to enable the formulation of longerrange objectives and to facilitate the necessary planning and implementation of longer-range goals.

\section{PROGRESS REPORT CONTENTS}

Program A - Genetic selection of superior trees, physiological basis of vigor, tissue culture, haploid cell lines and snmatir. hybridization, Brown - Steinbeck.

Program B - Physiology of Paraquat Induced Oleoresin Biogenesis. Brown.

Program C - The Biochemical Basis of Paraquat Induced Oleoresin Production in Pines. Finnerty.

Program D - The Biochemistry of Methanogenesis. Peck - Ljungdahl. 


\section{Abstract of Progress Report}

Research Program A: Genetic selection, physiological basis of vigor, tissue culture, haploid cell lines, and somatic hybridization.

\section{Investigators: Brown and Steinbeck}

Twelve exceptionally vigorous clones of American sycamore were selected from coppiced plantations, multiplied by stem cuttings, and outplanted on two widely different sites to study genotype $x$ site interactions for assessing relative performance of phenotypic selections. Variations in dry weights and inorganic nutrient content of above- and below-ground biomass of selected clones were studied to assess the basis for differences in inherent vigor and nutrient utilization. Callus formation (increase in cell number) of putative fast and slow growing clonal selections growing on chemically defined agar media was positively correlated with observed field performance in 5 out of 6 clones. Response of these same clones (stem cuttings) undex long and short day conditions in environmentally controlled growth chambers indicate that photoperiod per se may be used as a supplemental tool in early screening for inherent vigor. Long photoperiod significantly enhanced the numbor of nodes protuced and lenqth of internodes in a putative fast growing clone over that of a slower growing clone in paired observations. These studies indicate that rapid progress can be made in clonal. selections, and techniques for assessing inherently superior genotypes can be developed for greatly increasing total biomass production for fiber, feedstock, and fuels. 
PROGRESS REPORT

Research Program A: Genetic selection, physiological basis of vigor, tissue culture, haploid cell lines, and somatic hybridization.

Date: June, 1976

\section{Investigators: Brown and Steinbeck}

1. Work relative to "genetic selection"

Twelve selected clones of American sycamore were multiplied by stem cuttings and by branch cuttings.

Stem cuttings of the clones were outplanted on two upland sites (Whitehall and Grant Forests of the University of Georgia). Cuttings of 9 clones were planted at a $4 \times 8$ foot spacing with 5 cuttings per clone assigned to random plots within 9 random blocks on each site $(5$ cuttings $x 9$ clones $x 9$ blociks $=405$ stem cuttings plus necessary border rows on each site). The month-iong drought in April, 1976 led to the complete failure of the planting on the Grant Forest. Supplemental irrigation was available at the Whitehall Forest and this planting has survived to date.

Branch cuttings from 12 clones were propagated under mist in the greenhouse and newly constructed lath house. This was a new technique for this species in that it had not been tried en masse before. We planted 100 cuttings for each of the 12 clones in half-gallon tin cans filled with soilpeat mix. Three clones did not root well from branch cuttings. The other 9 clones produced at least 50 ramets each after a hardening-off period in the lath house. They are slated to be planted on a fertile bottomland site at the Whitehall Forest which was cleared of forest and plowed last year. 
Recent tornadic winds and heavy thunderstoms led to heavy flooding in this bottomland and the outplanting will be established as soon as it is dry enough: to plow.

These two plantings on widely differing sites should provide indications about genotype $x$ site interactions and the relative performance of the selected clones.

Plantations of sycamore seedlings mixed with alder were slated to be established. Due to a massive crop failure of sycamore in tree nurseries throughout the south, however, we were unable to secure sycamore seedlings: We did obtain 2000 black alder seedlings (of the 4,000 produced in Georgia) and are attempting to keep them alive. Hopefully sycamore seedlings (and perhaps alder seedlings) will be available this winter so that we can get the mixed plantation phase under way.

A graduate (M.S.) student with a biochemical background has been recruited. He will begin to develop techniques to assess carbohydrate storage and recycling in sycamore coppice this summer.

2. Work relative to "Physiological basis of vigor"

In July, 1975 we began sampling coppiced sycamore plantations to determine the variation among individual rootstocks with regard to biomass production and nutrient accumulation. The above-ground sprout portions (leaves, branches, stems and bark) were cut, separated, measured and analyzed for their nutrient contents. Root sampling procedures were developed and root stocks were excavated, measured and also analyzed for certain nutrients. These measurements are now being analyzed. Using biomass production as an indication of vigor, we hope to assess the extent of variability in.vigor as well as nutrient utilization among rootstocks. 
Attempts to Screen for Inherent Vigor Using Tissue Culture Techniques:

During July 1975, three putative fast and slow growing clones (total six)

of sycamore were selected from coppiced plantations and placed in tissue culture on defined agar media to study their relative proliferative ability and sustained rate of growth (cell division and callus formation). Six different types of basal media were tested. A satisfactory medium using the mineral nutrients of Murashige and Skoog, $3 \%$ sucrose, three of the B-vitamins, and glutamine, with low concentrations of gibberellic acid, 6 , benzyl adenine, and napthalene acetic acid was developed and is currently being used for sustained, continuous, growth of callus. Monthly observations, fresh and dry weights of callus explants, are positively correlated with field selections in 5 of the 6 clones selected. In one case, one of the putative'slow growing clones turned out to have a higher rate of cell division than two of the fast growing clones. Although these correlations between laboratory cultures and performance in the field appear very promising, one must be very cautious in drawing too rapid conclusions between clones. For example, the age of the tissue selected for culture (cambial, pith, or cortical cells), its location on the twig or sprout, and initial proliferative ability on a suitable growth medium, etc. all have to be carefully controlled.

Currently we are trying to extend the culture of callus cells on nutrient agar to liquid suspension to obtain more uniform rates of cell division, and hence better growth correlations between field selected high and low vigor clones. The callus is growing at a relatively moderate rate on the best agar medium developed, but it is very compact, light green to brown in color, and difficult to obtain in a friable condition for shaking into 
single cells or small clumps of cells in liquid suspension. Various treatments are now in progress to achieve rapidly growing liquid suspensions.

Photoperiodic Screening for Vigor: These same fast and slow growing clones, along with 6 newer selections during the dormant season (January, 1976) were propagated by stem cuttings for use in photoperiodic studies designed to screen for inherent vigor at an early age. In one preliminary study observations were made on the height growth (number of nodes and length of internodes) between a fast and slow growing clone under an 18-hour (long day) and 12-hour (short day) regime at constant temperature $\left(25^{\circ} \pm 2^{\circ} \mathrm{C}\right)$ in Percival growth chambers. The study could only be pursued for 90 days because of rapid height growth of both clones under the long day conditions, but even during this period there were significant differences in total height growth between the two clones under. Iong day conditions. Under short day conditions the differences were not significant but the variation in rooting response was extensive and limited or confounded the usefulness of the study.

All of the six selected clones have been out-planted in nursery beds for multiplying during the curxent growing season and new studies with these clones (fast and slow) are being established during the current growing season under greenhouse conditions where they can be adequately replicated and maintained for longer periods. Statistical analyses of growth response to long and short photoperiods of these clones will test the feasibility of this approach. Thus far, the use of photoperiod as a tool in screening for genetic potential per se appears to hold promise for woody perennial plants. 
Haploid Cell Lines: Preliminary attempts this spring (March, 1976) to develop haploid lines of sycamore from immature and nature microspores failed using the same culture media supporting the growth of diploid callus. This was not surprising since the same difficulties have arisen previously in the culture of haploid pine cells vs. diploid cells in our laboratory. After several dozen attempts we are now growing haploid cells of longleaf pine ( $\underline{P}$. palustris) in continuous cell suspensions and on nutrient agar on defined media. The nutrient requirements for each species vary consider$a b l y$, and in many instances without any easily recognizable or predictable nutritional differences. The medium which supports growth of haploid tobacco cells very quickly kills haploid pine cells and vice versa. The precise reason(s) are not known, hence much empirical research on media modifications are practiced by all workers engaged in plant cell and tissue cultures. In all of our attempts chemically defined media are used rather than plant extracts or other organic unknowns in an attempt to derive some of the basic nutritional parameters essential for growth and organ differentiation in both diploid and haploid cell lines. Sustained progress is being made, but it will take more time and additional concentrated effort to achieve the goal of producing and screening haploid plantlets for use in forest genetics research.

Somatic Hybridization Studies: We have not attempted somatic hybridization as yet with clones of sycamore or other economically valuable hardwoods in our program of short rotation, intensive culture of woody plants for increased fiber production. The reason for not doing so from an academic viewpoint may be difficult to justify; however, from a practical viewpoint it appears illogical to produce hybrid:cell combinations in the laboratoxy 
without first being able to achieve organ differentiation and recovery of the recombined genotypes. The most important approaches to be made now are those concerned with controlled growth and organ differentiation of both diploid and haploid lines (the best genotypes available from field performance) before proceeding with controlled laboratory hybridization procedures followed by recovery of hybrid genotypes and plantlet formation. Such a program may take years to attain success but we plan to pursue it actively in the years ahead because of the unsurpassed potentialities para-sexual approaches now offer to forest biology. See attached publication (Brown, 1976).

Publications and other activities:

1. Brown, C. L. 1976. Forests as energy sources in the year 2000: What man can imagine, man can do. Jour. For. 74: 7-12.

2. Steinbeck, K. and C. L. Brown. Yields and utilization of hardwood fiber grown on short rotations. See attached galley proof.

3. Brown was invited speaker to the national convention, society of American Foresters, Washington, D. C., September, to address members on "Forestry in the year 2000."

4. Steinbeck was invited and participated as panelist for the Bioconversion Conference on the topic of "Land and fresh water farming" held March 10-12, 1976 in Washington, D. C. 


\section{Abstract of Progress Report}

Research Program B: Physiology of paraquat induced oleoresion biogenesis. Investigator: Brown

Paraquat fed into the terminal leaders of five-year-old slash pine trees ( $\underline{P}$. elliottii) induced significant changes in mobilization and use of reserve fooods. Starch and free carbohydrate levels decreased rapidly during a four week period following treatment, accompanied by significant increases in fatty acids, monoterpenes and resin acids. Qualitative cytological examination of xylem parenchyma cells, phloem parenchyma, cortex, and pith using specific histochemical stains, confirmed localized mobilization ftarch and accumulation of oleoresins and lipids. Similar cytological results were obtained in slash pine cell suspension cultures at low paraquat concentrations $(0.1$ to $1.0 \mathrm{mg} / 1)$ in the chemically defined nutrient medium. At these paraquat concentrations, cell division is drastically inhibited, membrane permeability is altered, cytoplasmic stands disappear and cultured cells undergo general senescence. During a culture cycle of three weeks, starch, tannins, and soluble proteins decrease, whereas fatty acids increase for a short time before likewise decreasing. Resin acids do not increase in cell suspension cultures under the influence of paraquat probably because of leakage of precursors into the medium and the increased turnover rates of all metabolites in the cultured cells at approximately the same time. In in vivo (treated trees) paraquat adsorbs strongly to tracheid cell walls and moves slowly into the adjacent xylem pareuchyma cells inducing transport gradients and concomitaint gradients of oleoresin soaking both horizontally and vertically in the tracheids along the bole. 
Research Program B: Physiology of paraquat induced oleoresin biogenesis.

Principal Investigator: Claud L. Brown (Note: This program was combined with Research Program $C$ with William $R$. Finnerty because of final cut-back in funding.)

1. Physiological aspects relating to paraquat induced resin soaking in the xylem of slash pine.

During the summer of 1975 techniques were developed for injecting known quantities (various paraquat concentrations in fixed volumes of water $(10 \mathrm{ml})$ into the transpiration steam of terminal leaders on 5-year-old, plantation grown slash pine ( $\underline{P}$. elliottii) trees on a fairly uniform site. At the end of 4 weeks treated and control terminal leaders were collected for cytological observations and extracted for quantitative determinations of soluble carbohydrates, starch, fatty acids, monoterpenes, and resin acids. Paraquat was shown to have a mobilizing effect on stored foods in all living tissues of the stem causing a decrease in starch content, accompanied by an initial increase in fatty acids and a rapid increase in monoterpenes and resin acids (cf. preprint of paper by Brown, et al. attached herewith).

During the current year (June 1975-May 1976) cytological and quantitative observations were continued on diploid pine cells (Pinus elliottii) grown in cell suspension cultures. Paraquat was supplied to standard shake cultures in concentrations of $0.005,0.01,0.05,0.1,1.0$, and $10.0 \mathrm{mg} / 1$. Concentrations below 0.1 did not inhibit cell division or final cell size; neither did these levels promote significant increases in lipid or oleoresin formation in vitro. At $0.1,1.0$, and $10.0 \mathrm{mg} / 1$, initial increases in lipid content (free fatty acids) increased with time at the lower two levels 
up to 14 days, then they also began to decline. The quantities of resin lacids produced in liquid suspension culture were nil and could neither be consistently verified by gas chromatography nor confirmed by mass spectrophotometry. There is some indication, however, that large masses of (20-30 gms) slash pine callus cultures growing on defined agar produce resin acids if the callus is flooded with low concentrations of paraquat $(0.1-1.0 \mathrm{mg} / 1)$ two to three weeks prior to extraction. Apparently the altered metabolism of cultured cells and the absence of organized resin ducts in this tissue prevents resin soaking. Thin tissue slices of intact secondary xylem, phloem, cortex and pith are induced by paraquat to produce enough oleoresin to make pulse labeling with ${ }^{14} \mathrm{C}$ precursors feasible and this technique can now be used under aseptic conditions for short and long term feeding experiments.

Cytological observations of tissue culture cells using specific stains for lipids/oleoresin, tannins, starch, and lignin confirm the mobilizing effects of paraquat in vivo in bringing about visible reductions of tannins and starch accompanied by increases in lipid/oleoresin droplets within the cytoplasm of treated cells. In vivo observations of paraquat treated and control pine cells in suspension culture viewed under Nomarski optics reveal the deleterious effects of paraquat on breakdown of cytoplasmic strands and ultimate disintegration of plastids corresponding to concentration and length of treatment. These and other cytological observations, documented with appropriate photomicrographs are currently being prepared and summarized for publication.

Preliminary observations on the ultrastructure of pine cells treated with sub-lethal and lethal concentrations of paraquat both in vitro and in vivo are currently beiry extended in dopth (June-Septemher 1.976) in 
collaboration with Dr. W. R. Finnerty. These studies are concerned mostly with the effects of paraquat on membrane integrity, sites of oleoresin production, and changes in the structure of cellular organelles relating to altered biochemical pathways and induced oleoresin formation being studied in Dr. Finnerty's laboratory.

\section{Publications and other activities:}

Brown, C. L. and L. E. Nix. 1975. Uptake and transport of paraquat in slash pine. For. Sci. Vol. 21(4):359-364.

Brown, C. L., T.R.Clason, and J. Michael. 1976. Paraquat induced changes in reserve carbohydrates, fatty acids, and oleoresin content of young slash pines. Proceedings of Lightwood Research Coord. Council. January 1976, Jacksonville, Fla.

\section{Manuscript in preparation}

Brown, C. L. and T. R. Clason. Cytological and histochemical observations of paraquat treated pine cells in suspension cultures (Amer. J. Bot. or Bot. Gaz.)

Presented paper at Lightwood Research Coordinating Council Meeting, Jacksonville, Fla., January 20-21, 1976. 


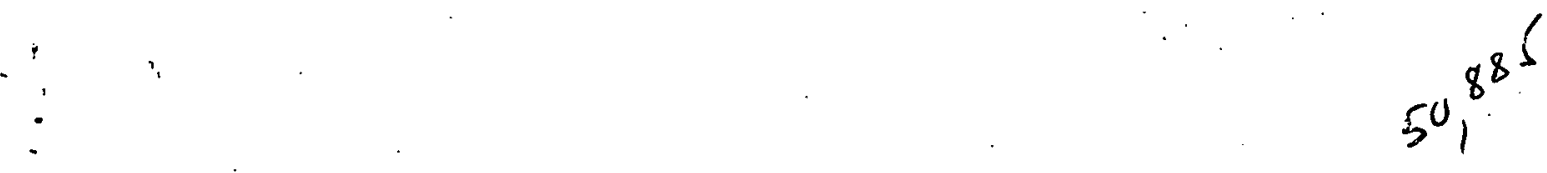

Project C. The Biochemical Basis of Paraquat Induced Oleoresin Production in Pines. Principal Investigator W. R. Finnerty.

\section{ABSTRACT}

The metabolic changes occurring in slash pine following the application of paraquat are accessible to biochemical analyses. The metabolic patterns observed reflect specific alterations in the levels of total keto-acids, soluble carbohydrate, and amino acids. The accumulation of keto acid suggests a possible metabolic relationship to the loss of soluble carbohydrate. A preliminary relationship between protein degradation induced by paraquat treatment and the concomitant accumulation of amino acids bears further consideration as a major pathway for carbon mobilization. The formation and existence of free radicals in biological systems has received experimental support, in turn, forming the basis for in vivo oxidation of unsaturated lipids. Increased peroxidative activity has been demonstrated in paraquat-treated slash pine. Results to late indicate that free fatty acid represents a minor component of the total lipid complement in both normal and paraquat-treated pine. Metabolic changes accompanying increased oleoresin synthesis, whether seasonal or paraquat-induced, are similar if not identical. Diverse data indicates the increased synthesis of resin is a "normal" wound and senescent response in pines. The paraquat effect on oleoresin synthesis is not an unique metabolic response but, rather, represents an acceleration of the normal pathways of terpene bio-synthesis. Paraquat stimulates a series of irreversible metabolic reactions of a catabolic nature providing carbon precursors for resin acids synthesis at sites yet undetermined. 
The research program for the past 12 months was composed of the following research personnel:

Dr. W. R. Finnerty, principal investigator.

Mrs. P. Kerr Falco, research associate, (Sept. 1975-to date) $100 \%$ time.

Dr. C. L. Scott, postdoctoral, (Sept. 1975-Jan., 1976) 100\% time.

Dr. Scott examined the ultrastructure characteristics of control and paraquat-treated cell suspension cultures and resin duct systems isolated from phloem tissue of field pines.

Mr. T. LeCroy, technician, (Feb. 1976-July 1976) $50 \%$ time, General metabolic studies.

Ms. J. Keel, technician, (Feb. 1976-May 1976) 50\% time, Lipid isolation, gas chromatography.

The results of the past years studies are summarized in the following progress report. Formal publications and presentations are:

\section{Publications:}

1. Biochemical Changes in Paraquat Treated Stems of Slash Pines. W. R. Finnerty, P. Kerr Falco, R. A. Makula, 1976, Proceeding of Annual Meeting Lightwood Research Council. USDA-US Forest Service, Lakewood, Florida, in press.

2. Metabolic Changes Associated with Paraquat Treatment of Pinus elliottii. 1976. Abstract. American Society for Plant Physiologists. P. Kerr Falco, and W. R. Finnerty, Vo1. 57, page 49.

\section{Meeting Presentations:}

1. A.tered Pathways of Metabolism and Biogenesis in Paraquat-Treated Trees. W. R. Finnerty, R. Makula, P. C. Kerr, 3rd Annual Lightwood Research Coordinating Council, Jan. 20-21, 1976, Jacksonville, Florida.

2. Metabolic Changes Associated with Paraquat Treatment of Pinus elliottii. Annual meeting American Society for Plant Physiologists, May 30, 1976. New Orleans, LA.

3. Primary Productivity as Related to Energy. W. R. Finnerty, invited spcalcer. International symposium to be held in Gottingen, Germany, Oct., 1976.

\section{Manuscripts in Preparation:}

1. Seasonal Metabolic Variations in Pinus elliotii. W. R. Finnerty and P. Kerr Falco.

2. Metabolic Changes in Pinus elliottii following Paraquat Treatment. A Field Study. W. R. Finnerty and P. Kerr Falco. 
Manuscripts in Preparation (Cont'd.):

3. Precursor Labeling of Resin Acids in Tissue Slices of Pinus elliottii. 


\section{INTRODUCTION}

The application of paraquat to pines was observed to stimulate increases in the amount of oleoresin produced during a specified growing season (Roberts, 1973). The biochemical and physiological basis for this increased production of oleoresin in pines remains undetermined. General physiological and biochemical effects resulting from the application of paraquat include inhibition of photosynthetic carbon dioxide fixation, alteration of the photosynthetic electron transport system in the chloroplast, ultrastructural changes, generalized decrease in cellular lipids, and stimulation of hydrogen peroxide formation. This research program has been divided into 4 topical areas:

a) lipid composition - qualitative and quantitative;

b) ultrastructure analysis of control and paraquattreated tissue;

c) model test systems for studying oleoresin formation;

d) biochemistry of oleoresin formation.

The results will be summarized under these 4 topical areas and collectively correlated in the Discussion section.

\section{Materials \& Methods}

The material and methods are generally as reported in the attached pre-print, Biochemical Changes in Paraquat Treated Stems of Slash Pines. Exceptions are as follows:

1) Small seedling studies were performed on 3-6 months old field grown seedlings that were transplanted in sand-soil mixture in the field and transferred to growth chambers as described in the text.

2) Tissues from certain isotope incorporation studies werc crtracted with $90 \%$ and $70 \%$ ethanol and water. In all isotope tissue studies, the growth supernatant was acidified (after the tissue was removed) and extracted with diethyl ether. Resin acid and volatile organic compounds were estimated from combined ethanol, diethyl ether, Et ${ }_{2} 0$, and/or $\mathrm{CHCl}_{3}: \mathrm{CH}_{3} \mathrm{OH}$ extracts. Wet chemical determinations were estimated from the combined ethanol-water extracts. .

Radioactivity was determined in a Nuclear of Chicago Mark III Liquid Scintillation counter. 
RESULTS

I - Lipid Composition -

The quantitation of phospholipid in control and paraquat-treated samples of Pinus elliottii ( $5 \mathrm{yr}$. stands) and cell suspension cultures were examined. Qualitatively, the phospholipids were chromatographically similar in field samples and cell suspension cultures. In addition, the qualitative composition of phospholipids in control and paraquattreated tissues were not altered significantly. We were able to resolve 5 major phospholipids with several minor phosphate-positive components. The 5 major phospholipids were tentatively identified as phosphatidylcholine, phosphatidylinositol, phosphatidic acid and 2 major unknowns that were not conventional types of phospholipids. The phospholipids were not pursued further as to chemical identification but, rather, were subjected to quantitative analyses as a total polar lipid constituent of the sample. Quantitative analyses of control and paraquat-treated samples were compared to assess loss of phospholipid following paraquat treatment. Table 1 illustrates the quantitative relationships between needles and stem sections of $\underline{P}$. elliottii.

Paraquat-treated tissues from both field and tissue culture failed to show a significant difference in phospholipid content when compared with control samples. Numerous analyses failed to exhibit significant quantitative differences in.paraquat-treated specimens either short-term or long-term.

Total lipid extracts derived by chloroform-methanol extraction of tissues were fractionated by silicic acid column chromatography. The neutral lipids were recovered by chloroform elution, glycolipids by acetone elution and phospholipids by methanol elution.

The neutral lipid fraction consisted of 3 major lipids - a sterol (probabiy sitosterol), triglyceride, and a component tentatively identified as monoglyceride.

The glycolipid fraction consisted of 5 glycolipids which were separated into 2 monoglucosyl diglyceride components and 3 diglucosyldiglycerides. Further characterization of these lipids was not pursued since no apparent differences were observed in paraquat-treated tissues.

The phospholipid fraction consisted of the previous stated composition and was not pursued further as to structural elucidation.

\section{II - Ultrastructural Analyses -}

An extensive analysis of fixation methodology for electron microscopy was initiated to develop optimum schedules for tissue preparation. Studies of cell suspension cultures and on stem segments where the resin duct system was physically isolated were developed. We were able to generate thin-sections of the above tissue specimens as follows: 
Fixation: $\quad 2 \%$ glutaraldehyde in $0.1 \mathrm{M}$ cacodylate buffer for a minimum of 3 hours. Rinsed overnight and treated with $2 \% \mathrm{OsO}_{4}$ in $0.1 \mathrm{M}$ cacodylate buffer for 3 hours.

Dehydration: $\quad 50 \%$ Durapan -1 hour

70\% Durcupan - 1 hour

90\% Durcupan - 1 hour

$100 \%$ Durcupan - 1 hour

100\% Durcupan - 1 hour

Embedment: $\quad 25 \%$ Spurr -1 hour

$50 \%$ Spurr - 1 hour

$75 \%$ Spurr -1 hour

$100 \%$ Spurr -1 hour

$100 \%$ Spurr -1 hour

These preparative conditions have been found to result in thin-sections that were acceptable for transmission electron microscopy.

Examination of thin-sections prepared from isolated resin ducts (control and paraquat-treated specimens) and from cell suspension cultures (control and paraquat-treated) did not reveal any striking fine-structure differences. Most membranes remained generally intact without any extensive indications of massive breakdowns or disorganization. Paraquat-treated tissues appeared to become more vacuolated and generally contained less cytoplasm. Further work is in progress this summer in collaboration with Dr. C. Brown to obtain more definitive evidence for fine-structure alterations in cell suspension cultures following paraquat treatment.

III and V - Model Systems and Biochemistry of Oleoresin Production

I. Seasonal variation in soluble pool components from Pinus elliottii.

Phloem, xylem, and needle samples from the terminal leaders of $5 \mathrm{yr}$. old trees were sampled monthly to ascertain the seasonal variation (if any) of resin acids and certain total soluble pools implicated in oleoresin synthesis. The branch was sub-divided into node, 1-2 in. above node, and stem sections. Resin acid content was estimated from $\mathrm{CHCl}_{3}: \mathrm{CH}_{3} \mathrm{OH}$ extracts $(2: 1)$ by gas chromatography, ninhydrin, anthrone, 2,4-dinitrophenylhydrazine, and thiobarbituric acid reactivities were determined from $70 \%$ ethanol. extracts.

Data presented in Tables 3, 4, 5, and 6 indicate that seasonal differences in ninhydrin, anthrone, 2,4-dinitrophenyl hydrazine, and thiobarbituric acid reactivities, respectively, axe associated with a fluxation in the total resin acid as determined by thin-layer chromatography. In general, all soluble pools increased contingent with increased flow of oleoresin in late winter and early spring (January through March).

Field observations indicate that onset of meristematic activity,i.e., flowering and/or vegetative growth, (late March - early May) was accompanied by a precipitous decline in anthrone reactivity from approximately $100 \mathrm{mg}$ to $40 \mathrm{mg} / \mathrm{gm}$ fresh weight (Table 4). Hydrazine reactivity increased 3-4 
fold during the February to March sampling period and returned to its anticedent level during the March to April sampling period (Table 5). Neither the ninhydrin nor the thiobarbituric acid reactive components varied as much as the sugar and ketoacids (Tables 3,6 ).

Active guttation of oleoresin declined with onset of increased meristematic activity. Differences in total amino acid content were observed during this period between wet (guttating resin) and dry branches. Data presented in Table 7 indicate that the developing bud and phloem of dry branches contained 1.5 - 2 times more free amino acid than those of guttating branches. No differences were apparent in the xylem of the two branches. Apparently, monoterpene synthesis was also retarded during this period, because their characteristic aroma was not noticeable in either control or paraquat-treated field tissues. Laboratory experiments (data reported in Laboratory section of this report) also indicated that synthesis of volatile organic compounds was minimal during March-April.

II. Metabolic Changes Associated with Paraquat Treatment of Pinus elliottii.

1. Field Studies

In early July, 1975, twenty-five (25) 5 year old trees were treated with a total dose of $2 \mathrm{mg}$ commercial Paraquat. The terminal leader of each tree was treated with $10 \mathrm{ml}$ of $0.02 \%$ paraquat through a cut lateral branch. Twenty-five trees were selected as non-cut control trees at this time. Five treated and five control trees were harvested $3,7,14,21$, and 28 days after treatment. Ninhydrin, anthrone, 2,4-dinitrophenylhydrazine, and 2 thiobarbituric acid reactivities were determined from $70 \%$ ethanol extracts. Total lipid phosphorus and total and free fatty acids were estimated from $\mathrm{CHCl}_{3}: \mathrm{CH}_{3} \mathrm{OH}$ extracts by the method referred to in preprint. Starch wâs determined by the method referred to in preprint, and the resulting glucose estimated by the anthrone procedure (preprint., Brown, et al.). Total resin acids and monoterpenes were est: nated from diethyl. ether extracts by gas chromatography (preprint, Brown, et al.) Details of this experiment are reported in the two attached preprints from the Jacksonville, Florida Meeting of the Lightwood Council.

In September, 1975,5 trees were treated with $200 \mathrm{mg}$ paraquat as described in the July experiment ( $10 \mathrm{ml}$ of $0.2 \%$ paraquat soln). Five trees were cut in the same manner as the treated trees to serve as controls. A treated and a control tree were harvested after $1,2,4,7$, and 14 days (Tables 8, 9, $10,11)$.

Since the metabolic changes and absolute amounts of material measured in both the cut control and the paraquat-treated tissue were similar (Table $8,9,10,11$ ), non-cut controls trees were harvested also on days 7 and 14 . Only the ninhydrin (Table 8 ) and anthrone (Table 9) reactive materials show clear cut differences between control and treated material. 
Free amino acids (Table 8) increased approximately 2 times in paraquat-treated tissue. Anthrone values measured on day 1 were higher $(37.5$ versus $32.5 \mathrm{mg} / \mathrm{gm}$ fresh weight in treated tissue) Values varied from $7-3 \mathrm{mg} / \mathrm{gm}$ fresh wt. through day 14. A maximum of 32.5 $\mathrm{mg} / \mathrm{gm}$ fresh wt was measured in the control on day 2 and varied thereafter from 2.5 to $6 \mathrm{mg} / \mathrm{gm}$ fresh wt.

Trees were treated with $2 \mathrm{mg}$ paraquat in mid-March, 1976, but no effect from this treatment was apparent. This time coincided with increased meristematic activity, decreased oleoresin flow, and apparently decreased synthesis of oleoresin.

\section{Laboratory Studies}

\section{A. Tissue Culture}

The paraquat effect on liquid tissue culture cells will be reported in detail by $\mathrm{C}$. Brown. This system was not used in these metabolic studies since the cells are apparently incapable of synthesizing oleoresin under. the present culture condition. Preliminary studies indicate that callus tissue may synthesize oleoresin and may respond to paraquat.

B. Small Seedling

hundred

Three 6 months old Pinus elliottii seedlings were obtained from the Georgia State Forestry Commission Nursery at Macon, Georgia, transplanted into sandsoil mixtures in the field, and transported to growth chambers in Athens, Georgia. After a three week recovery period $\left(20^{\circ} \mathrm{C}\right.$, approximately $300 \mathrm{ft}$. candles white fluorescent light, no humidity control) a lateral branch was cut and $5 \mathrm{\mu c}$ (total volume $5 \mu 1$ ) each of glucose $-U-14 \mathrm{C}$, acetate-2-14 C, ${ }^{14} \mathrm{C}$-amino acid mixture (uniformly labeled algal hydrolyzate) and mevalonic acid-4-5-3 $\mathrm{H}$ were placed on stumps. The solutions were taken up immediately. Five days later the seedlings were harvested and extracted with $\mathrm{CHCl}_{3}: \mathrm{CH}_{3} \mathrm{OH}(2: 1)$ (Table 12). Radioactivity was not detectable in the glucose and acetate treated tissues. Although $2500 \mathrm{CPM}$ were recovered from the mevalonic acid treated seedling, no radioactivity was detectable in either resin acid or triglycerides. Amino acid $-14 \mathrm{C}$ incorporation resulted in the recovery of $93,500 \mathrm{CPM}$ in $\mathrm{CHCl}_{3}: \mathrm{CH}_{3} \mathrm{OH}$ soluble material. Of this total activity, $4 \%(3,840$ CPM) wàs recovered in resin acid and $8 \%$ (7480 CPM) was recoverdd in triglyceride. Ten times more activity 
was recovered from the hydrolyzed insoluble residue.

Leucine-4,5- ${ }^{3} \mathrm{H}$ plus or minus paraquat was placed on the cut stump of a branch of 6 month old pine seedlings. Ten days later the seedlings were harvested and the tissue extracted with $\mathrm{CHCl}_{3}: \mathrm{CH}_{3} \mathrm{OH}$. Radioactivity was detected only in control tissue (Table 12). Approximately $0.53 \%$ of this activity (200 CPM) was recovered in resin acids. Paraquat appeared to be transported to the roots in this experiment since the roots and associated microflora appeared to be dead in the treated seedlings.

C. Tissue Slices

Experiments using slices of phloem and xylem from terminal leaders of field grown 5 yr old Pinus elliottii have been performed from January, 1976 to date. Tissue (5 gm fresh wt xylem; $2.5 \mathrm{gm}$ fresh wt. phloem) was incubated for various periods of time in $50 \mathrm{ml}$ of sterile $0.01 \mathrm{M}$ phosphate buffer, pH6.5 containing radioactive substrates in the presence of absence of $1 \mathrm{mg}$ paraquat. One $\mathrm{ml}$ of water was added to the control flasks.

Glucose-U- ${ }^{14} \mathrm{C}$; glycine-2- $-{ }^{14} \mathrm{C}$; acetate-2- ${ }^{14} \mathrm{C}$; leucine $-4,5-3_{\mathrm{H}}$; mevalonic acid $-4,5-{ }^{3} \mathrm{H}$; phenol-U-14 $\mathrm{C}$, cinnamic acid and dihydroxypheny1alanine (DOPA) have been used as substrates. Data from all of the experiments will not be included, but representative data from the two types of response to glucose will be included. (Tables $13,14,15,16,17,18$ ). Summary data on incorporation of label into the volatile organic fraction (Table 19) and resin acids (Table 20) from all of the experiments will be included.

Glucose $-{ }^{14} \mathrm{C}$ incorporation into terpenes appears to vary seasonally (Tables 19, 20). Declining incorporation of glucose-14 C into both the volatile organic fraction and resin acid fraction was apparent from January to June. Sap fluw dild oleoresin guttation increased markedly in early January (unseasonally warm sunny days willi some nights below freezing temperatures). The tree needles were frozen on at least 3 mornings in late January - early February. In late March, 
meristematic activity increased; both flower and vegetative buds expanded until late May, 1976. Concomitant with the increased growth rate, oleoresin guttation was reduced or totally stopped (40 trees were sampled in the field for guttation in mid-April and only ten trees (25\%) were guttating at that time). The characteristic aroma of monoterpenes was not noticeable in the field nor from cut branches from the field. Data included in Table 7 indicate that the amino acid content of wet (guttating) and dry (not guttating) tissues are different. Amino acid content of wet tissue is approximately 2 times that of non-guttating tissue. Xylert values are again the same in both tissues.

During this same period of time, growth and sporulation of the fungus, Cronartium fusiforme, was very obvious on most of the trees in the Athens area, including the plantation used in this study. The trees had apparently been infected during the entire study, but active growth of the fungus was restricted to April through mid-May. Ninhydrin reactive material from infected and noninfected tissues are presented in Table 21. Perhaps not surprisingly, free amino acids are approximately 3-4 fold higher in fungal cankers than in tissues not visibly infected.

In contrast to growing tissues in the field, all of the soluble components tended to decrease with time in both paraquat treated and control tissues (Tables 13,15). Amino acids were the only soluble pool component that increased following paraquat treatment and then decreased in both the treated and control tissues in those cases. where glucose- ${ }^{14} \mathrm{C}$ was lincurpulated into resin acid (Table 15). In those exceptions where glucose-14C was not incorporated into resin acids, amino acid levels were not elevated over those of the control in paraquattreated tissues (Table 15).

D. Enzymology

Attempts to isolate soluble protein preparations capable of syntheslzing terpenes have bcen futile to date. Extracts of cells from liquid tissue culture and callus were both negative. Since the liquid cultures appear to be incapable of making resin acids this is not surprising. Extraction of protein from phloem and wood separately or cumbined have had limited success. Small amounts 
of total protein can be extracted with phosphate buffer $\left(10^{-3}-10^{-1} \mathrm{M}\right)$ and $\mathrm{NaCl}(1-3 \mathrm{M})$, but no incorporation of labeled mevalonate into resin acids has been observed.

\section{DISCUSSION}

Paraquat treatment of intact seedlings (Table 12j) five year old trees (preprint) and xylem and phloem tissue slides (Table 13, 15, 19, 20) of Pinus elliottii was accompanied by metabolic changes in certain soluble pool components and oleoresin production. Amino acids and terpenes generally increased following paraquat treatment in both in vivo and in vitro systems (Preprint; Table 3, 13). TBA, 2,4-dinitrophenylhydrazines, and anthrone reactive matexials tended to increase in vivo in paraquat-treated material (Preprint) but no differences were apparent in control and treated tissues in vitro(Tables 4, 5, 6). Disappearance of starch accompanied paraquat-treatment in vivo, (PreprintBrown, et al.) but this parameter was not estimated in vitro. Estimates of free reducing sugars yielded inconsistant trends which may indicate that these compounds are undergoing rapid turnover following paraquat treatment.

The source of the increased amino acid pools is unknown at this time. Decreased protein synthesis, increased protein hydrolysis, and/or conversion of carbohydrate or other soluble components into amino acids are possible pathways.

Protein syntehsis appears to be inhibited when plant tissues undergo dessication (Dhindsa and Bewley, 1975). In general, paraquat treatment of $\mathrm{P}$. elliottii tended to reduce the water content of affected areas, and could thereby inhibit protein synthesis. Label from glycine-2-14 C and uniformly ${ }^{14} \mathrm{C}$-labeled algal protein hydrolyzate was recovered in acid hydrolyzates of ethanol and water-insoluble plant residues. Radioactivity was recovered at the $\mathrm{Rf}$ of several common amino acids after development in butanol-acetic acid-water on Whatman \#1 f1lter paper. These data would indicate that some protein synthesis was occurring in paraquattreated tissue, but no attempt to estimate exchange was done.

Attempts to estimate proteolysis have been unsuccessful. Materials that interfere with the Lowry protein determination were extracted from the tissues with both $70 \%$ ethanol and water. Azoalbumin and several other artificial substrates cannot be used because colored compounds absorbing at the same wavelength as that of the artificial substrates are extracted by the buffers, salts, and solvents used for protein extraction.

Samples are presently being analyzed on the Beckman amino acid analyzer to ascertain the composition and concentration-of amino acids following paraquat-treatment. If these data are not available for inclusion in this report, they will be included in preprints. Hydrolysis of starch to glucose and its conversions 1nto anillo acid carbon via ketoacids is a possible pathway. 
Ketoacids (2,4-dinitrophenylhydrazine reactive materials) increased following paraquat-treatment in vivo (Preprint). Attempts to identify specific ketoacids have been unsuccessful to date. Isolation and identification attempts utilized TLC (on cellulose bicarbonate plates) of nonradioactive hydrazones.

TBA reactive materials are assumed to be related to the peroxidation of fatty acids (Baumgartner, et al., 1975) (Baker, Wilson, 1966). TBAreactive materials increased in vivo following paraquat-treatment (Preprint). Autoxidation of fatty acids and polyunsaturated esters produced compounds that induced both reversible and non-reversible biochemical and morophological damage (Baker \& Wilson, 1966; Schausenstein, 1967). Inhibition of two SH enzymes, glyceraldehydephosphate dehydrogenase and lactate dehydrogenase, by these peroxidation products were reported by Schausenstein (1967). Neither fructosediphos: iphosphate, aldolase, hexokinase, or glucose-6-phosphate dehydrogenase were inhibited by the peroxidation products. These data could indicate that specific blocks in carbohydate metabolism could result from paraquat-treatment if peroxidation of acids occurred. Norphological changes were ohserved by Schausenstein (1967) as a result of peroxidation products, and Dodge and Harris (1972) reported extensive structural damage in flax cotyledons following paraquat-treatment.

Brown, et a1. (this report) observed structural damage in paraquattreated liquid tissue cultures cells of $\underline{P}$. elliottii. Phospholipid analysis of control and paraquat-treated trees in vivo did not support the concept of extensive structural damage in these trees (Preprint). If extensive membrane destruction occurred, the phospholipid content would probably be much lower than that of the control.

In summary, in vivo paraquat treatment of 5 year old pine trees resulted in apparent decreased water and starch content of affected tissues with increased amounts of amino acids, ketoacids, and TBA-reactive materials in association with increased oleoresin synthesis. Trends in free reducing sugar were inconsistent from experiment to experiment and time to time. The observation of increased starch hydrolysis following paraquat treatment is most interesting in light of the known interaction between gibberellic acid $\left(\mathrm{GA}_{3}\right)$ and activities of $\alpha$-amylase and certain proteinases (Yomo, 1960; Paleg, 1960, 1965) $\mathrm{GA}_{3}$ is a degraded diterpene produced from the mevalonic acid pathway (Goodwin, 1967). If GA synthesis were stimulated by paraquat treatment, many of the metabolic changes associated with paraquat activity could be directly related to hormonal regulation of protein synthesis and/ or release. Seasonal variation in free reducing sugar and presumably starch also indicate that increased available anthrone reactive material was associated with increased guttation and synthesis of oleoresin in late winter and early spring (Table 4). In analogy of seed germination of barley (Yomo, 1960; Paleg, 1960), increased sap flow and metabolic activity in southern pines could be regulated by $\mathrm{GA}_{3}$ and its associated increase in hydrolytic enzymes making more carbon available for resin synthesis. TBA and ninhydrin reactive materials also increased during this period (Table 3). Increased ketodcids were observed only during 
March (Table 5) when a precipitous decrease in reducing sugars was observed (Table 4).

Collectively these data indicate that the metabolic changes accompanying increased synthesis of oleoresin by $P$. elliottii, whether seasonally or paraquat induced, are similar if not identical. (Tables 3, 4, 5, 6, and Preprint). Data collected from cut control tree (Table 8, 9, 10, 11), from tissue studies (Tables 13, 15), and from knowledge of the methods used to collect oleoresin in the naval stores industry indicate that increased synthesis of resin is a "normal"wound and senescent response in southern pines. Oleoresin is collected normally in late winter and early spring by an axe hatch on the bole of the tree. The cut surface is painted with. $\mathrm{H}_{2} \mathrm{SO}_{4}$ biweekly to "maintain an active resin flow." When pines are cut and the boles and/or stumps are allowed to lie for several years, they become "resin soaked". Thus, increased carbon flow into oleoresin is associated with injury and "death" of the tissue.

Screens of paraquat analogs performed by the manufacturer of paraquat (personal communication from Empirical Chemical Company, England) indicate that oleoresin synthesis stimulation was associated only with those compounds that exhibited herbicide activity. The paraquat effect on oleoresin synthesis is apparently not a unique metabolic response, but an acceleration of the normal pathway of terpene biosynthesis.

Small seedlings (3-6 months old) and tissue slices of phloem and xylem were labeled with ${ }^{14} \mathrm{C}$ - and ${ }^{3} \mathrm{H}$-substrates in the presence and absence of paraquat to ascertain possible precursor-product relationship. Radioactivity from glucose, glycine, leucine, algal hydrolyzate, mevalonic acid, cinnamic acid and phenol have been recovered to a greater or lesser extent in volatile organic compounds and resin acids (Tables 19, 20). Label from acetic acid-2-14C was incorporated extensively into the tissues and label was recovered in high yield from the triglycerides (Table 17), but only $1 \%$ of the label was recovered in the resin acid fraction (Table 20). Only 3 to $4 \%$ of the label from mevalonic acid $4,5-3_{\mathrm{H}}$ was recovered in the resin acid fraction (Table 20) though a relatively high percentage (20-50\%) of the total incorporated radioactivity was recovered in the volatile compounds (Table 19). Difficulties with mevalonic acid uptake by biological tissues have been reported (Loomis 1967), and the low incorporation of label into the terpenes could be explained by lack of uptake of the substrate. Reduced uptake cannot explain the lack of recovery of label from the resin acids when acetic acid-2-14 $\mathrm{C}$, the direct precursor of mevalonic acid, was the substrate.

Dramatic differences were apparent in the percent of the glucose carbon recovered in the volatile compounds and the resin acid from January through June (Table 19, 20). No glucose label was recovered in either fraction; i.e., volatile organic compounds and resin acids, from $4 / 5$ until the experiment of 6/1/76 (Table 19, 20): This period coincided with the onset of meristematic activity and the initiation of both flower and vegetative growth. Total expansion of the new growth appeared to be reached in late May. During this period of new growth, guttation of oleoresin ceased in 75-80\% of the trees, and the typical and distinctive aroma of monoterpenes was not detectable in either field or laboratory. Ten trees treated with $2 \mathrm{mg}$ of paraquat in the field during. this period did not respond to the treatment. Loomis (1967) reported a comparable cessation of monoterpene 
synthesis during flowering in mint. Apparently the developing tissues act as sinks for the soluble pool components, and perhaps for the terpenes as well (Table 21). Total amounts of terpenes as well as their synthesis and guttation were lower during this time of rapid tissue growth.

Amino acid concentrations were different in guttating (wet) and nonguttating (dry) branches during this period. Approximately 2-3 times more ninhydrin positive material was present in the dry branches (Table 7). The developing buds of the dry branch also contained appreciably more amino acids than those of the wet branches (Table 7 ).

Many pine trees in Georgia are infected with the fungus Cronartium fusiforma which was undergoing rapid growth and sporulation during this same period of time. Anino acid concentrations were, not surprisingly, very high in the branches infected with the fungus (Table 21). What effect, if any, the fungus may have had on the results of this study are not known, but it was apparent during April and May that the majority of the trees $(95 \%)$ in the plantation used for this study was infected with the fungus, though it was non-growing throughout most of the year.

With the exception of amino acids, soluble pools components decreased in both control and treated tissues in vitro (Tables 13, 15). This decrease could be due to a general decline in metabolic activity and structural integrity in the artificial system. Increased amounts of diethyl ether soluble products in the aqueous supernatant with time could support this hypothesis (Table 18). Amino acid patterns from experiments in which glucose- $14 \mathrm{C}$ was incorporated into resin acids differed from that when glucose- ${ }^{14} \mathrm{C}$ was not incorporated into resin acids (Tables 13, 15). Amino acid content did not increase over that of the control in those cases where label was not recovered in volatile compounds and resin acids. Field and laboratory wet chemical and laboratory labeling data indicate an association of terpene synthesis with mobilization and utilization of amino acid carbon. How direct a precursor and what specific amino acids are involved in the transfer of carbon is not known at this time.

Attempts to isolate active soluble enzyme preparation from mature tissues of $\underline{p}$. elliottii have been futile. Beylla el al. (1969) and Nascimento et a1. (1969) reported the isolation of enzymes capable of transforming mevalonic acid into isoprenoid compounds from 30-45 day old seedlings of Pinus radiata. The majority of the label was recovered in terpenols and only $0.05 \%$ of the incorporated mevalonate was recovered in hydrocarbons. The activity of a nonspecific acid phosphatase exceeded that of mevalonic kinase 3-5 fold under experimental conditions to minimize phosphatase activity. This reaction could account for lack of label in the hydrocarbons.

Information obtained from Emperial Chemical Company (personal communication) indicate that stimulation of mevalonic kinase activity cannot explain increased synthesis of terpenes following paraquat treatment. 
Low rates of incorporation of label into terpenes from acetic acid-2- ${ }^{14} \mathrm{C}$ and mevalonic acid-4-5 ${ }^{3} \mathrm{H}$ in this study and those reported by Loomis (1967), Beytia et al. (1969), and Nascimento et al. (1969) could indicate that. the 1) classical mevalonic acid pathway is not functional in terpene biosynthesis or that 2) these compounds are labeled from more than one metabolic pathway. Incorporation of glucose, glycine, leucine, algal protein hydrolyzate, phenol and cinnamic acid carbon into terpenes could indicate multi pathway labeling of terpenes. Paraquat-treatment does not appear to induce new metabolic pathways in $\underline{P}$. elliottii, but does appear to mobilize and shunt an increased amount of cellular carbon into the terpene biosynthetic pathway resulting in an accelerated rate of, but not necessarily increased amount of, oleoresin over what the tree would normally have produced in a longer period of time. 


\section{REFERENCES}

1. Baker, N. and L. Wilson, 1966. J. of Lipid Res. 1:341-348.

2. Baumgartner, W. A., N. Baker, V. A. Hill, and E. T. Wright, 1975. Lipids. 10:309-311.

3. Beytia, E., P. Valenzuela and 0. Cori, 1969. Arch. Biochem. Biophys. 129:346-356.

$4, \therefore$ Dhindsa, R. S., and J. D. Bewley, 1975. Science. 191:181-182.

5. Goodwin, T. W. 1967. Terpenoids in Plants. edited by J. B. Pridham, Academic Press, New York. pp 1-23.

6. Harris, N. and A. D. Dodge, 1972. Planta 104:210-219.

7. Loomis, W. D. 1967. Terpenoids in Plants, edited by J. B. Pridham, Academic Press, New York, pp. 59-80

8. Nascimento, G., C. E. Beytia, A. R. Aedo, and O. Cori. 1969. Arch. Biochem. Biophys. 132:470-4\%6.

9. Paleg, L. G., 1960. Plant Physio1. 35:293, 902.

10. Paleg, L. G., 1965. A. Rev. P1. Physiol. 16:291.

11. Sehausenstein, E. 1967. J. Lipid Res. $8 \div \div 417-428$.

12. Yomo, H. 1960. J. Ferment. Ass. Japan. 18:500, 600, 603. 
Table 1

Phospholipid Quantitation of $\underline{\mathrm{P}}$. elliotii (5 yr)

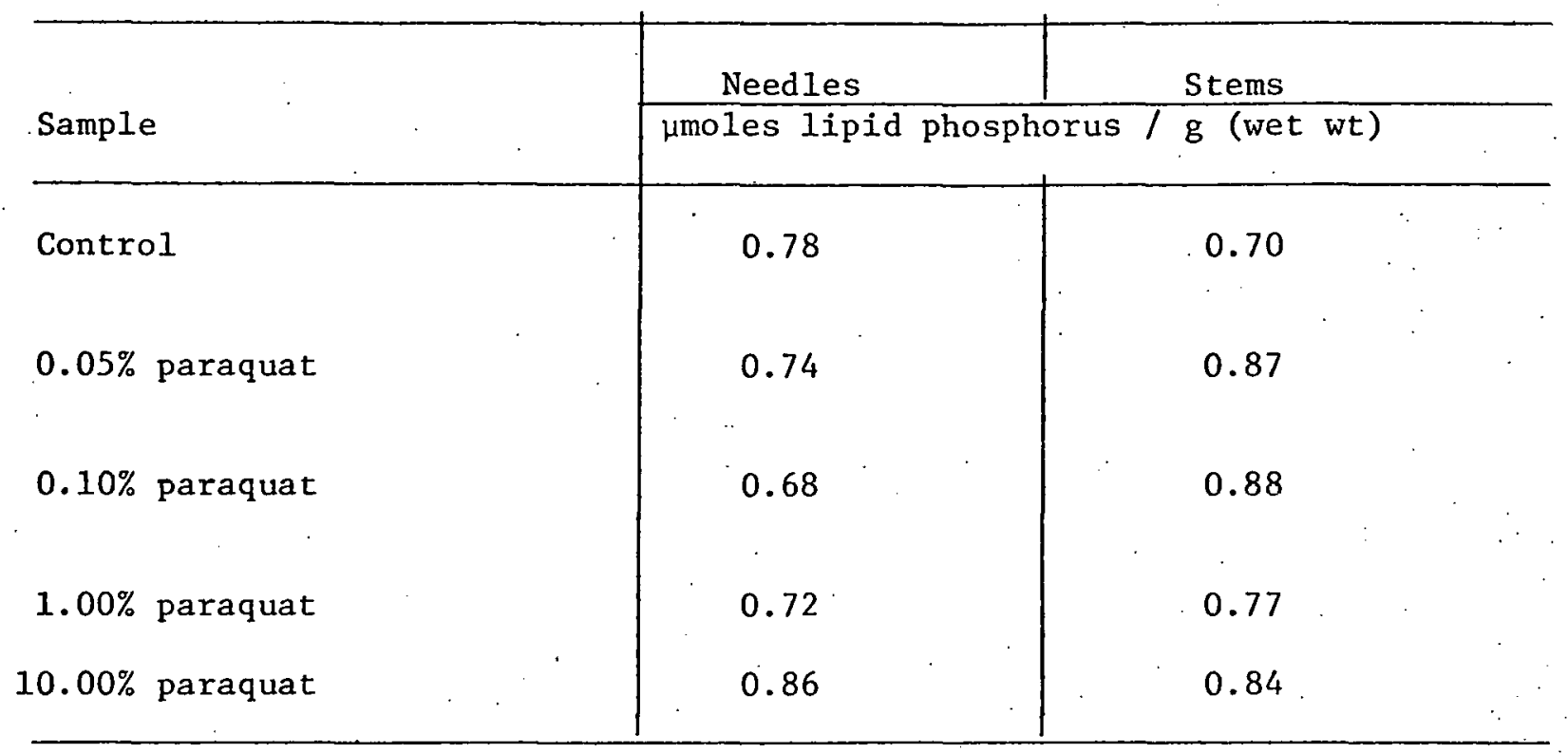

Table 2 illustrates representative data obtained from cell suspension cultures.

Table 2

Phospholipid Quantitation of Cell Suspension Cultures

\begin{tabular}{l|c|c}
\hline & Control & paraquat-treated \\
\hline Time & umoles lipid phosphorus / g (dry wt) \\
\hline 3-days & 38.9, & 37.5 \\
\hline
\end{tabular}


Table 3. Ninhydrin Reactive Materials from Node and Stem Sections of Terminal Leaders of 5 year old Pinus elliottii - ug/gm fresh weight

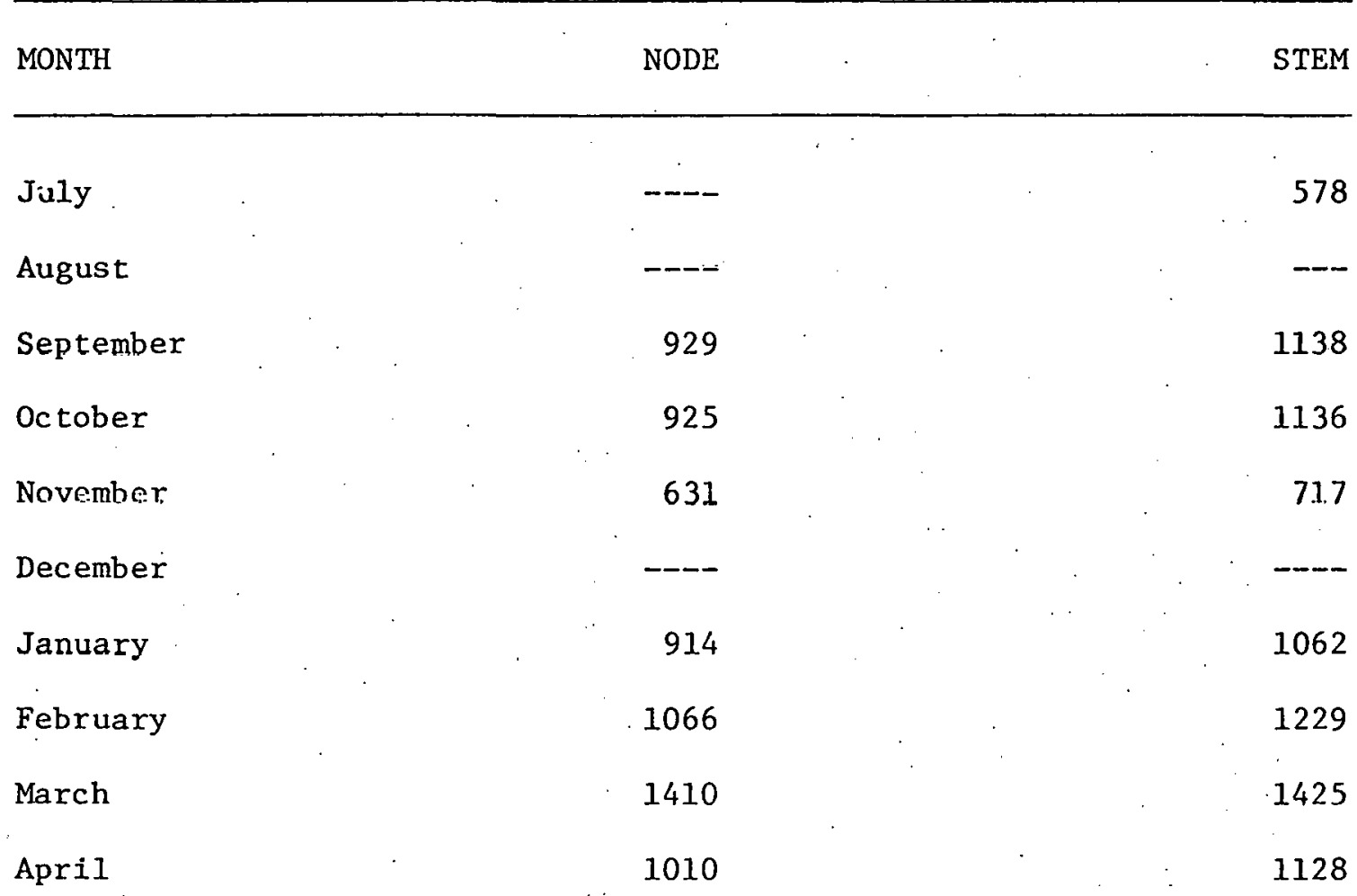


Table 4. Anthrone Reactive Materials from Node and Stem Sections of Terminal Leaders of 5 year old Pinus elliottii - ug/gm fresh weight

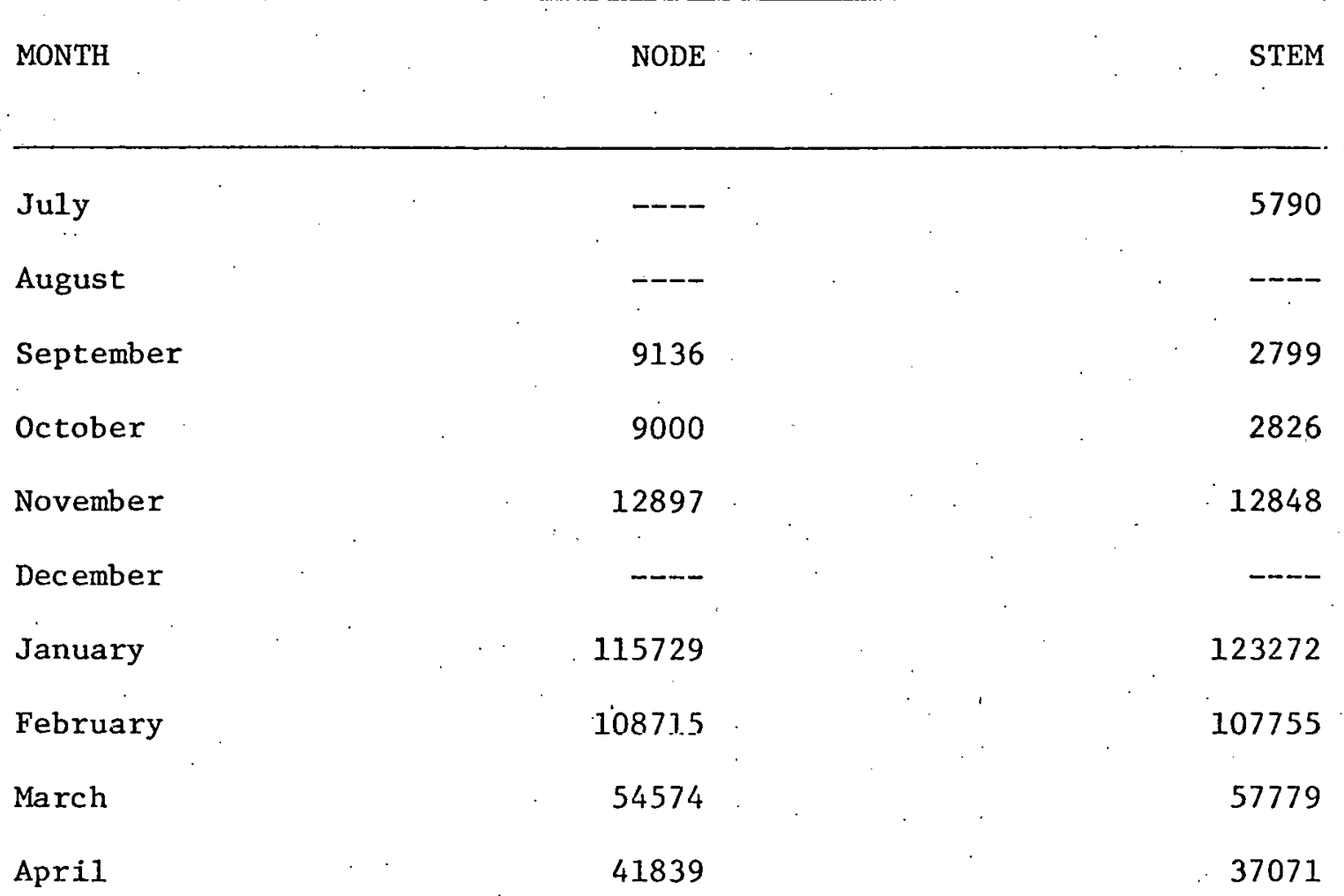


Table 5. 2,4, Dinitrophenylhydrazine Reactive Material from Node and Stem Sections of Terminal Leaders of 5 year old Pinus elliottii - OD/gm fresh weight

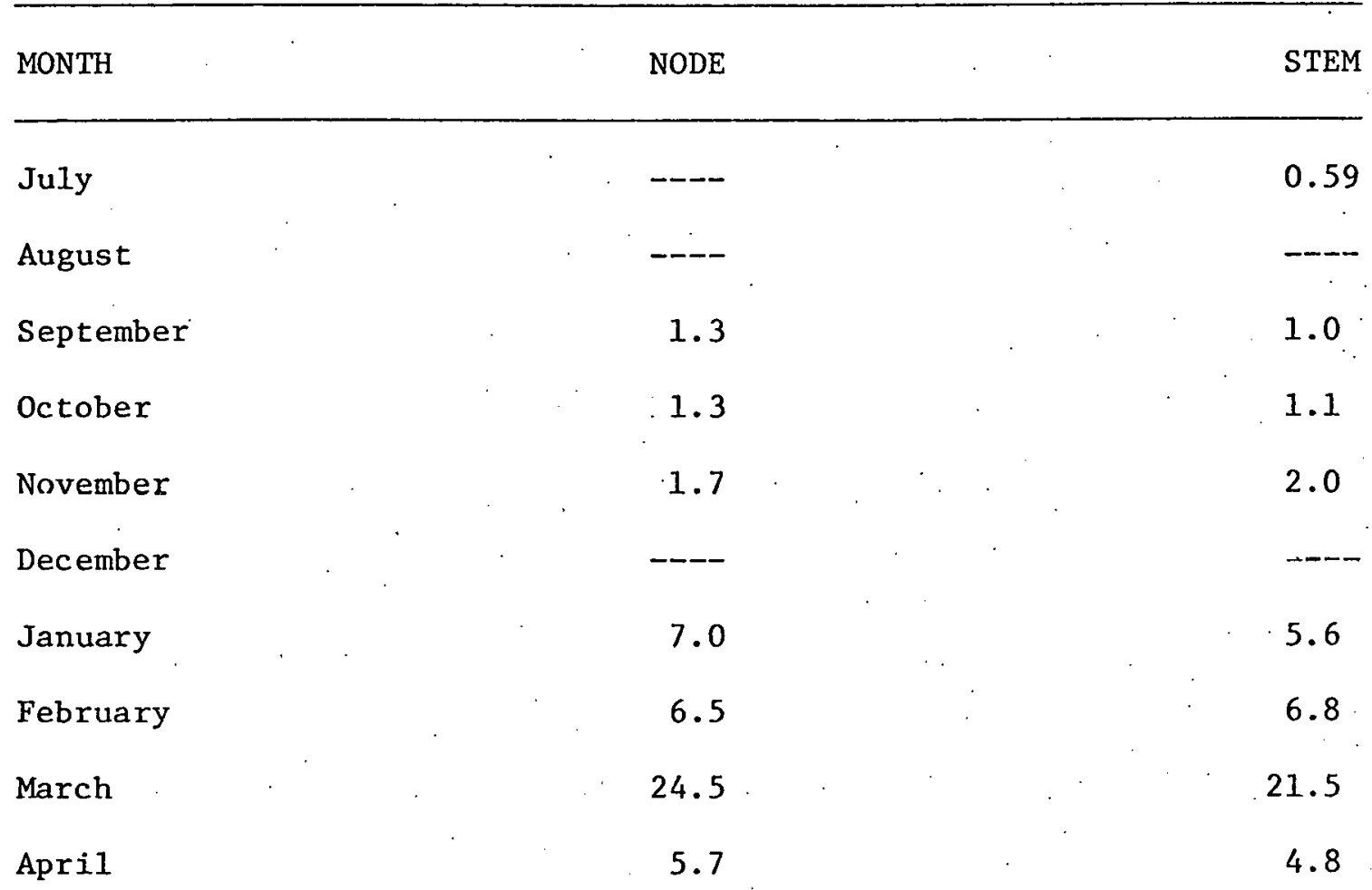


Table 6. 2-Thiobarbituric Acid Reactive Material from Node and Stem Sections of Terminal Leaders of 5 year old Pinus elliottii oD/gm Fresh Weight

\begin{tabular}{|c|c|c|c|}
\hline MONTH & NODE & & STEM \\
\hline July & --- & & 1.8 \\
\hline August & $-\cdots$ & & --- \\
\hline September & 1.9 & & 4.3 \\
\hline October & 2.1 & & 4.0 \\
\hline November & 2.6 & & 2.6 \\
\hline December & $-\cdots$ & & $-\cdots$ \\
\hline January & 7.3 & & 7.5 \\
\hline February & 16.3 & & 16.9 \\
\hline March & 13.4 & & 9.2 \\
\hline April & 11.9 & & 11.1 \\
\hline
\end{tabular}


Table 7. Ninhydrin Reactive Material from "Wet" and "Dry" Terminal Leaders of 5 years old Pinus elliottii - ug/gm Fresh Weight

\begin{tabular}{l|ccc} 
TISSUE & WET & DRY \\
\hline Bud & 262 & 418 \\
Phloem & 532 & 906 \\
Xylem & 373 & & 348 \\
& & & \\
\hline
\end{tabular}


Table 8. Ninhydrin Reactive Material from Cut Controls, Non-cut Controls, and Paraquat Treated Pinus elliottii - September, 1975 - ug/gm Fresh Weight

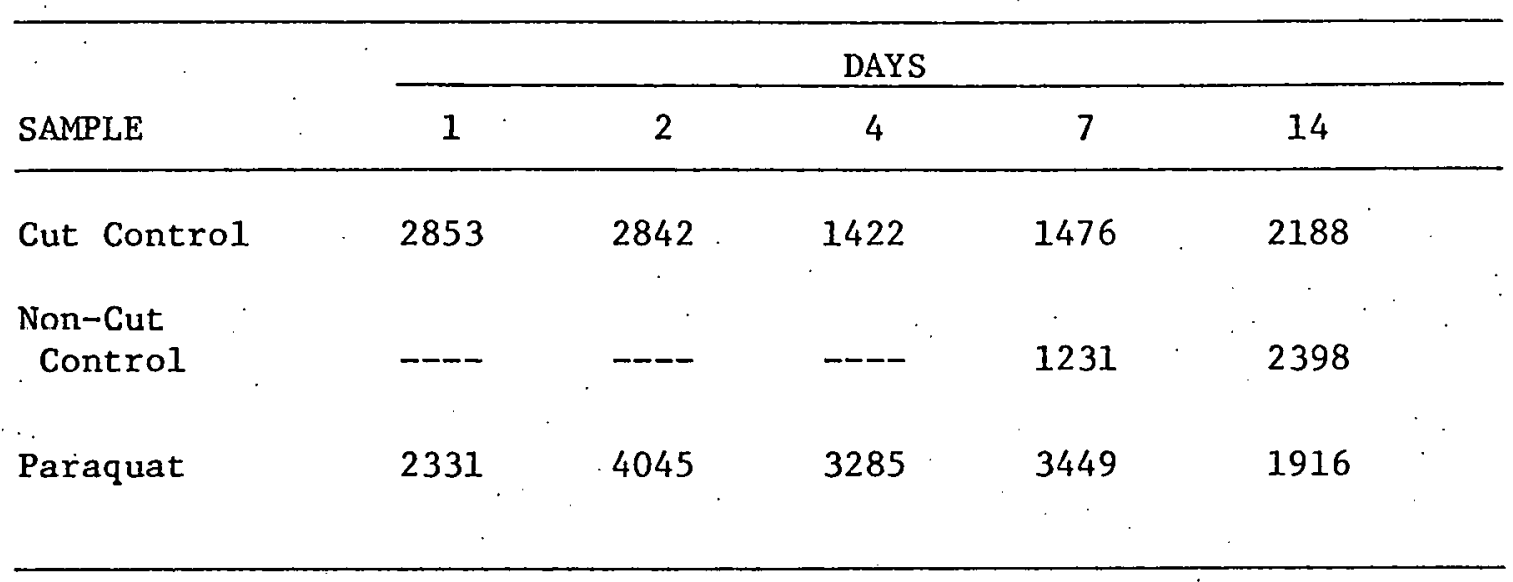


Table 9. Anthrone Reactive Material from Cut Controls, Non-cut Controls, and Paraquat Treated Pinus elliotti - September, 1975 - ug/gm Fresh Weight

\begin{tabular}{|c|c|c|c|c|c|}
\hline \multirow[b]{2}{*}{ Samples } & \multicolumn{5}{|c|}{ DAYS } \\
\hline & 1 & 2 & 4 & 7 & 14 \\
\hline Cut Control & 23,962 & 32,502 & 4430 & 6108 & 4954 \\
\hline $\begin{array}{l}\text { Non-cut } \\
\text { Control }\end{array}$ & - & ---- & --- & 7463 & 6150 \\
\hline Paraquat & 37,561 & 7264 & 4640 & 6938 & 3430 \\
\hline
\end{tabular}


Table 10. 2,4-Dinitrophenylhydrozine Reactive Material from Cut Controls, Non-cut Controls, and Paraquat Treated Pinus elliottii - September, 1975 - ug/gm Fresh Weight

\begin{tabular}{|c|c|c|c|c|c|c|}
\hline \multirow[b]{2}{*}{ Sample } & \multicolumn{5}{|c|}{ DAYS } & \\
\hline & 1 & 2 & 4 & 7 & 14 & \\
\hline Cut Control & 4.4 & 5.0 & 1.8 & 1.9 & 2.0 & \\
\hline $\begin{array}{l}\text { Non-cut } \\
\text { Control }\end{array}$ & --- & -- & $-\cdots$ & 3.0 & 1.8 & \\
\hline Paraquat & 3.9 & 4.5 & 2.1 & 1.9 & 2.3 & . \\
\hline
\end{tabular}


Table 11. 2-Thiobarbituric Acid Reactive Material from Cut Controls, Non-cut Controls, and Paraquat Treated Pinus elliottii -. September, 1975 - ug/gm Fresh Weight

\begin{tabular}{lccccc}
\hline & \multicolumn{5}{c}{ DAYS } \\
\cline { 2 - 6 } SAMPLE & 1 & 2 & 4 & 7 & 14 \\
\hline & 12.6 & 5.1 & 3.7 & 3.7 & 3.0 \\
Cut Contro1 & -5.3 & 4.8 & 4.0 & 3.1 & 2.5 \\
$\begin{array}{l}\text { Non-cut } \\
\text { Contro1 }\end{array}$ & -5 & & & 4.2 & 4.1 \\
Paraquat & 8.3 & & & & \\
\hline
\end{tabular}


Table 12. Radioactivity Recovered in $\mathrm{CHCl}_{3}: \mathrm{CH}_{3} \mathrm{OH}$ Extract of 3-6 Months 0ld Seedlings of Pinus elliottii after Five Days Exposure to Radioactive Substrates

\begin{tabular}{lcccc}
\hline Substrate & $\begin{array}{l}\mathrm{CPM} \\
\mathrm{CHCl}_{3}: \mathrm{CH}_{3} \mathrm{OH}\end{array}$ & Resin Acids & Triglycerides & $\begin{array}{c}\text { Protein } \\
\text { Hydrolyzate }\end{array}$ \\
\hline $\begin{array}{l}\text { glucose-U- }{ }^{14} \mathrm{C} \\
\text { acetate-2- }{ }^{14} \mathrm{C}\end{array}$ & 0 & 0 & 0 & 0 \\
$\begin{array}{l}\text { amino acid } \\
\text { mixture-U- }{ }^{14} \mathrm{C}\end{array}$ & 93,500 & 0 & 0 & 0 \\
$\begin{array}{l}\text { mevalonate } \\
4,5^{3}-\mathrm{H}\end{array}$ \\
$\begin{array}{l}\text { Leucine-* } \\
4,5^{3} \mathrm{H}\end{array}$ & 2,500 & 3,840 & 7,480 & 935,000 \\
& 37,735 & 0 & 0 & 0 \\
\hline
\end{tabular}

* 10 days exposure to radioactive substrate

- no sample 
Table 13. Wet Chemical Data from Glucose-U- ${ }^{14}$ C Experiment - 2/17/76 Label Recovered in Resin Acids

\begin{tabular}{llllll}
\hline & \multicolumn{5}{c}{ HOURS } \\
\cline { 2 - 5 } Sample & 17 & 24 & 48 & 72 \\
\hline Control & 3.9 & 4.5 & 3.7 & 4.5 & 2,4 -dinitrophenylhydrozine \\
Paraquat & 3.0 & 3.6 & 3.4 & 3.2 & OD/gm Fresh Weight
\end{tabular}

$\begin{array}{llllll}\text { Control } & 29,778 & 25,102 & 15,811 & 13,207 & \text { Anthrone } \\ \text { Paraquat } & 35,065 & 23,721 & 19,887 & 17,261 & \text { ug/gm Fresh Weight }\end{array}$

\begin{tabular}{llllll}
\hline Contro1 & 382 & 245 & 188 & 365 Ninhydrin \\
Paraquat & 642 & 536 & 392 & 401 ug/gm Fresh Weight \\
\hline Control & 4.7 & 5.4 & 4.3 & 4.0 & 2-Thiobarbituric Acid \\
Paraquat & 4.7 & 5.4 & 3.8 & 3.5 & OD/gm Fresh Weight \\
\hline
\end{tabular}


Table 14. Radioactivity Recovered in Various Fractions Following Exposure of Phloem and Xylem to Glucose-U- ${ }^{14} \mathrm{C}$.

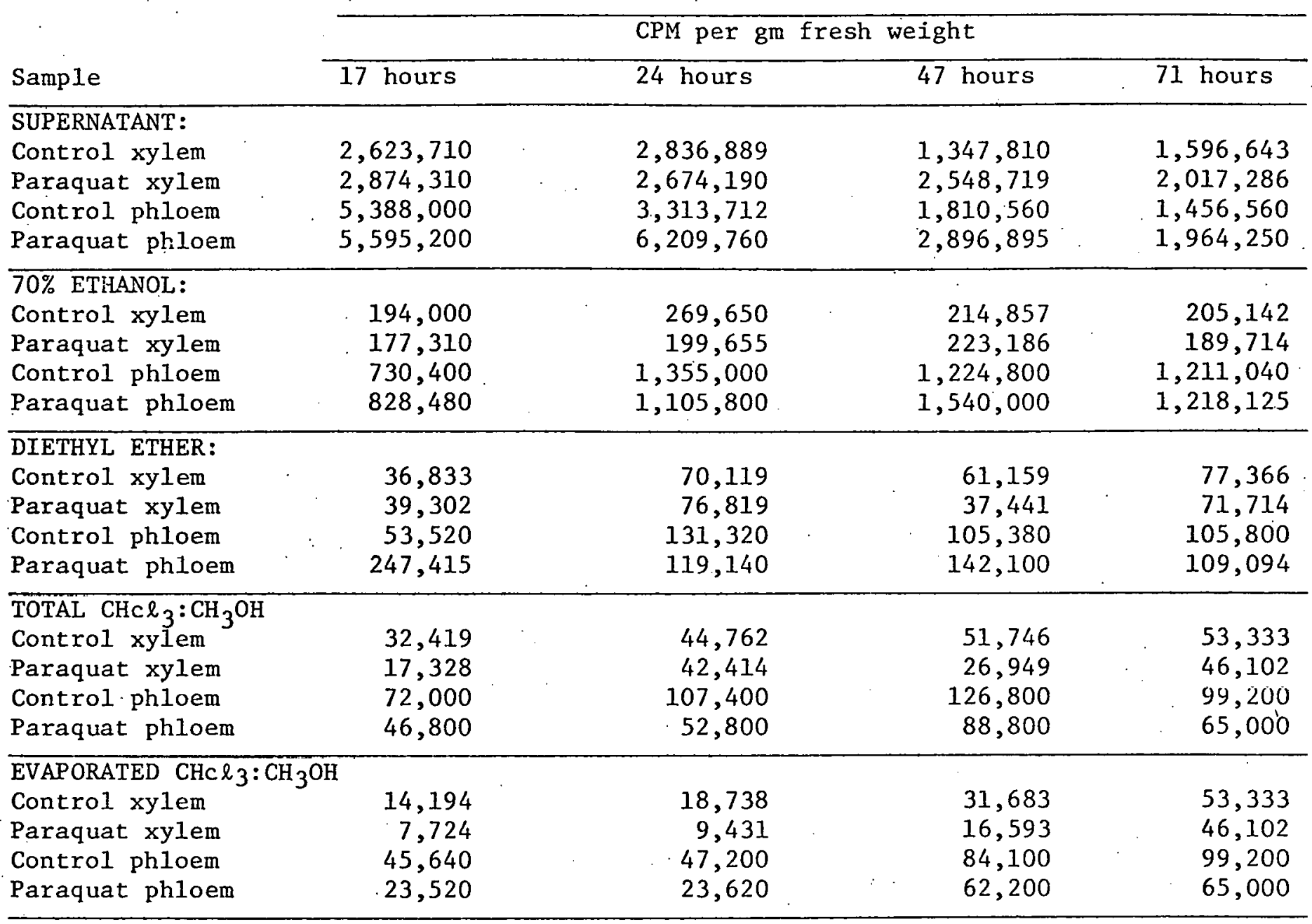


Table 15. Wet Chemicals Data from Glucose-U- ${ }^{14}$ C Experiment 4/5/76 Label Not Recovered in Resin Acid

\begin{tabular}{|c|c|c|c|c|c|c|}
\hline \multirow[b]{2}{*}{ SAMPLE } & \multicolumn{5}{|c|}{ HOURS } & \\
\hline & 6 & & 12 & 24 & 48 & \\
\hline Contro1 & 8.3 & & 7.1 & 6.1 & 4.7 & 2-Thiobarbituric Acid \\
\hline Paraquat & 8.8 & & 4.8 & 6.0 & 3.7 & OD/gm Fresh Weight \\
\hline Control & 429 & & 414 & 603 & 713 & Ninhydrin \\
\hline Paraquat & 279 & & 300 & 562 & 522 & ug/gm Fresh Weight \\
\hline Control. & 9,648 & & 7,155 & 7,655 & 5,770 & Anthrone \\
\hline Paraquat & 10,385 & & 7,035 & 8,770 & 6,375 & ug/gm Fresh Weight \\
\hline Contro1 & 2.5 & & 2.8 & 3.8 & 3.6 & 2,4-dinitrophenylhydrozine \\
\hline Paraquat & 3.1 & 1 & 1.9 & 3.7 & 2.6 & OD/gm Fresh Weight \\
\hline
\end{tabular}


Table 16. Total Radioactivity Recovered in $90 \%+70 \% \mathrm{C}_{2} \mathrm{H}_{5} \mathrm{OH}+\mathrm{C}_{2} \mathrm{H}_{5} \mathrm{OH}_{5} \mathrm{C}_{2}$, and Water Extraction of Phloem and Xylem Tissues of Pinus elliottii Following Exposure to Glucose-U- ${ }^{14} \mathrm{C}$ for the Times Indicated. Labe1 not Recovered in Resin Acids

\begin{tabular}{lcccc}
\hline & \multicolumn{4}{c}{ HOURS } \\
\cline { 2 - 5 } SAMPLE & 6 & 12 & 24 & 48 \\
\hline Control Phloem & 660,880 & 723,540 & 874,440 & 825,840 \\
Paraquat Phloein & 870,800 & 615,780 & 830,800 & 914,400 \\
Control Xylem & 360,700 & 421,110 & 542,040 & 917,910 \\
Paraquat Xylem & 361,470 & 355,850 & 706,410 & 684,050 \\
\hline
\end{tabular}


Table 17. Percent Radioactivity Recovered in Triglycerides Following Exposure to Substrates for the Indicatec Times.

\begin{tabular}{|c|c|c|c|c|c|c|c|c|c|c|c|c|}
\hline Substrate & & glucos & $e-U-14 c$ & . & g1ycine-2C14 & leucine $-4,5,{ }_{\mathrm{H}}^{3}$ & acetate $2-{ }^{14} \mathrm{C}$ & mevalonate $4,5^{3} \mathrm{H}$ & phenol-U- ${ }^{14} \mathrm{C}$ & Cinnamic actd & DOPA & glucose \\
\hline $\begin{array}{l}\text { Time- } \\
\text { Hours } \\
\end{array}$ & 17 & 24 & 48 & 72 & 24 & 24 & 24 & 24 & 24 & 24 & 24 & $2 \dot{4}$ \\
\hline $\begin{array}{c}\text { Contro1 } \\
\text { Xylem }\end{array}$ & $6.9^{1}$ & $6.3^{1}$ & $6.1^{2}$ & $13.2^{1}$ & $31.9^{1}$ & $4.0^{1}$ & & $2.0^{1}$ & 2.4 & 0.9 & 1.0 & 2.3 \\
\hline $\begin{array}{l}\text { Paraquat } \\
\text { Xylem }\end{array}$ & $36.8^{1}$ & $18.0^{1}$ & $.19 .8^{2}$ & $26.1^{2}$ & $18.2^{1}$ & $3.0^{1}$ & & $2.0^{1}$ & $-\infty$ & $\cdots$ & ---- & \\
\hline $\begin{array}{r}\text { Control } \\
\text { Phloem }\end{array}$ & $22.2^{2}$ & $16.4^{1}$ & $14.0^{2}$ & $21.4^{1}$ & $20.4^{1}$ & $9.0^{1}$ & $60.0^{1}$ & $3.3^{1}$ & 1.4 & 1.0 & 2.0 & 2.4 \\
\hline $\begin{array}{l}\text { Paraquat } \\
\text { Phloem }\end{array}$ & $72.9^{1}$ & $29.6^{1}$ & $74.7^{2}$ & $46.9^{1}$ & $17.6^{1}$ & $3.0^{1}$ & $\because \quad 55.0^{1}$ & $2.8^{1}$ & $\cdots$ & $\cdots$ & --- & \\
\hline
\end{tabular}

1- $\mathrm{C}_{2} \mathrm{H}_{5} \mathrm{OH}_{5} \mathrm{C}_{2} \mathrm{CHCl}_{3}: \mathrm{CH}_{3} \mathrm{OH}$ extracts

2- $\mathrm{CHCl}_{3}: \mathrm{CH}_{3} \mathrm{OH}$ extract 
Table 18. Percent Dilthylether Soluble Material of Total Radioactivity in the Culture Supernatant

\begin{tabular}{|c|c|c|c|c|c|c|c|}
\hline \multicolumn{8}{|c|}{ Substrate glucose } \\
\hline Time-hours & & 6 & 12 & 17 & 24 & 48 & 72 \\
\hline \multicolumn{8}{|l|}{ Sample } \\
\hline \multirow[t]{3}{*}{ Control Xylem } & $2 / 17$ & + & - & 1.4 & 2.5 & 4.5 & 4.8 \\
\hline & $3 / 18$ & 0.06 & 0.2 & - & 1.4 & 7.6 & - \\
\hline & $4 / 5$ & 0.06 & 0.07 & - & 0.5 & 2.7 & - \\
\hline \multirow[t]{3}{*}{ Paraquat Xylem } & $2 / 17$ & & - & 1.4 & 2.9 & 1.5 & 3.6 \\
\hline & $3 / 18$ & 0.08 & 0.2 & - & 1.2 & 4.7 & - \\
\hline & $4 / 5$ & 0.04 & 0.06 & - & 0.3 & 4.7 & - \\
\hline \multirow[t]{3}{*}{ Control Phloem } & $2 / 17$ & & & 0.9 & 3.9 & 5.8 & 7.0 \\
\hline & $3 / 18$ & 0.09 & 0.3 & & 3.4 & 7.8 & \\
\hline & $4 / 5$ & 0.03 & 0.05 & - & 0.2 & 0.4 & - \\
\hline \multirow[t]{3}{*}{ Paraquat Phloem } & $2 / 17$ & - & - & 4.4 & 1.9 & 4.9 & 5.6 \\
\hline & $3 / 18$ & 0.1 & 0.4 & - & 3.1 & 10.0 & - \\
\hline & $4 / 5$ & 0.05 & 0.05 & - & 0.3 & 0.9 & - \\
\hline
\end{tabular}

\begin{tabular}{l|c|c|c|c} 
Substrate & glycine & acetate & mevalonate & leucine \\
\hline Time-hours & 24 & 24 & 24 & 24 \\
\hline Sample. & 0.27 & 5.0 & 3.6 & 26.2 \\
\hline $\begin{array}{c}\text { Control } \\
\text { Xylem }\end{array}$ & 3.7 & 4.5 & 3.6 & 11.0 \\
\hline $\begin{array}{c}\text { Paraquat } \\
\text { Xylem }\end{array}$ & 3.7 & 4.7 & 4.6 & 10.3 \\
\hline $\begin{array}{c}\text { Control } \\
\text { Phloem }\end{array}$ & 3.2 & 4.5 & 4.3 & 6.3 \\
\hline $\begin{array}{c}\text { Paraquat } \\
\text { Phloem }\end{array}$ & & & &
\end{tabular}


Table 19. Percent of Total Radioactivity Lost when Sample was Evaporated to Dryness under vacüo

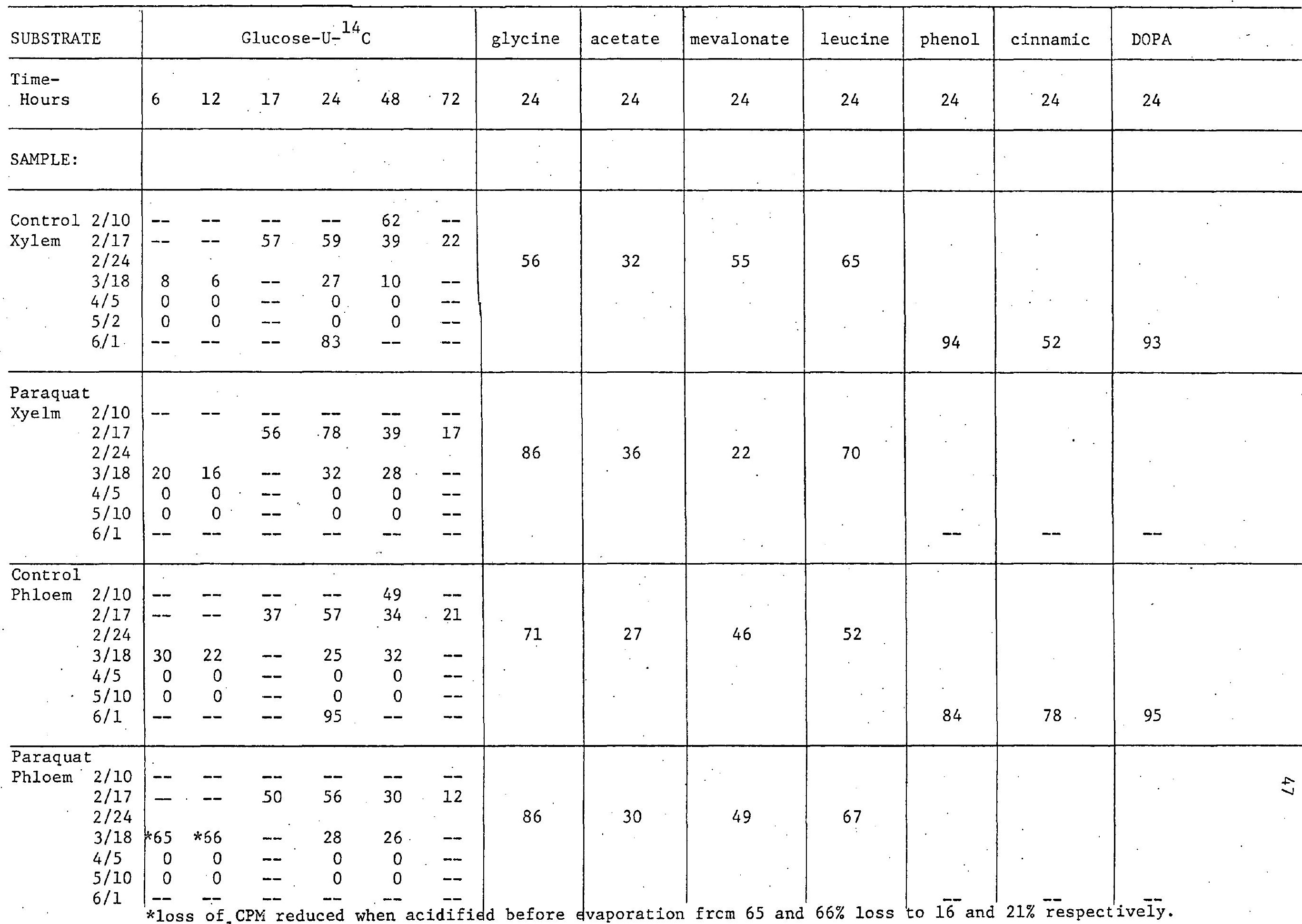


Table 20. Percent of Total Radioactivity Recovered in Resin Ac1ds after Exposure to Substrates for the Indicated Times.

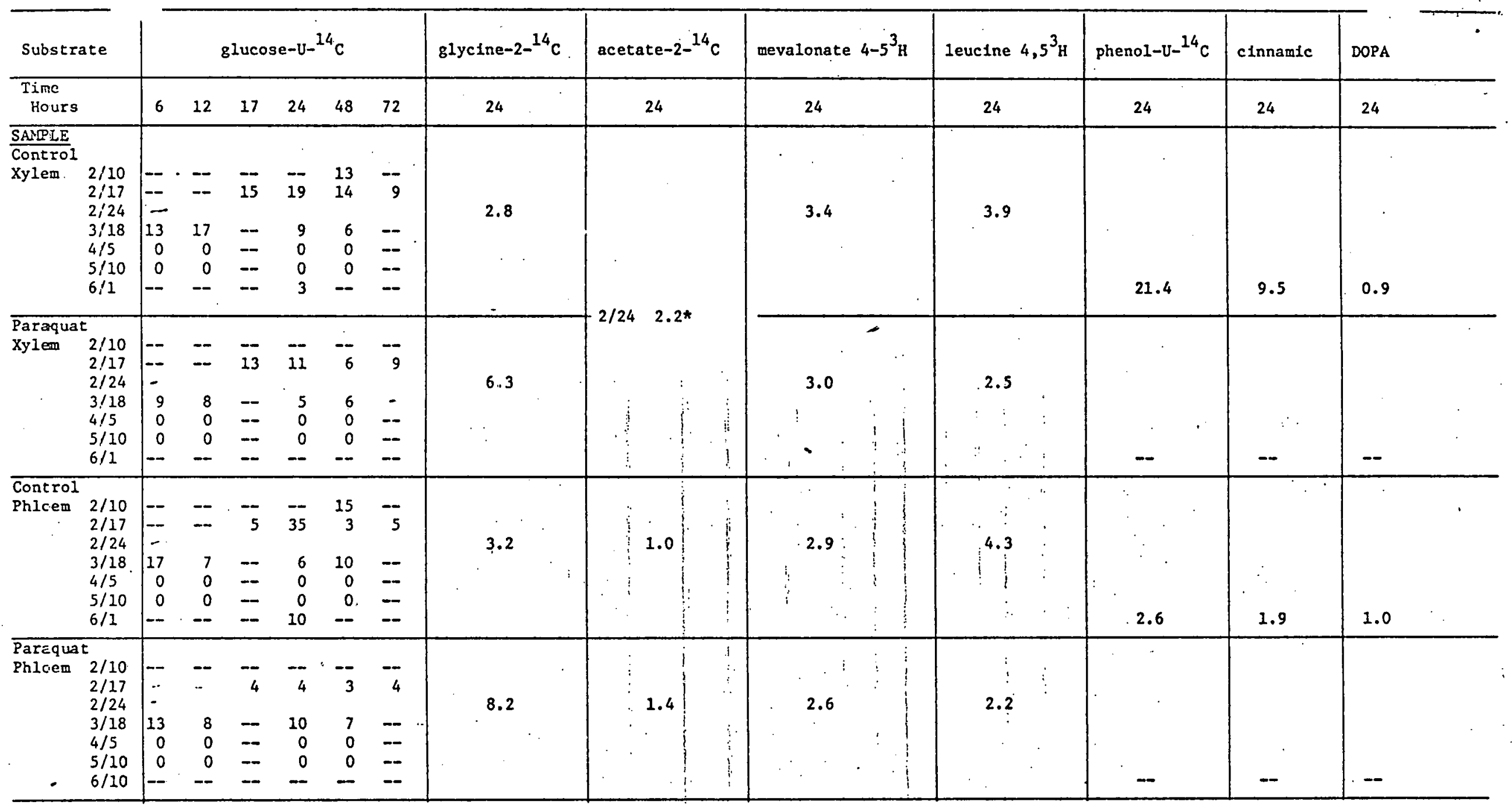

*-samples combined

- no sample 
Table 21. Ninhydrin Reactive Material in Tissues of Pinus elliotti Infected and Non-infected with the Fungus, Cronartium fusiforme, during Active Bud Growth and No Active Bud Growth - ug/gm Fresh Weight

\begin{tabular}{|c|c|c|c|c|}
\hline \multirow[b]{2}{*}{ Sample } & \multirow{2}{*}{$\begin{array}{l}\text { No fungus } \\
\text { "dry" } \\
\text { Bud not grow- } \\
\text { ing }\end{array}$} & \multirow{2}{*}{$\begin{array}{l}\text { No fungus } \\
\text { "dry". } \\
\text { Buds growing }\end{array}$} & \multicolumn{2}{|c|}{ fungus infected } \\
\hline & & & $\begin{array}{l}\text { Tip of } \\
\text { Branch }\end{array}$ & $\begin{array}{l}\text { fungus } \\
\text { canker }\end{array}$ \\
\hline Bud & -- & 418 & --- & --- \\
\hline Phloem & 2313 & 1728 & . & \\
\hline Xylem & 525 & 400 & & \\
\hline Needles & 400 & 325 & -- & --- \\
\hline
\end{tabular}

*samples combined

-no sample 
D. PROGRESS REPORT: BIOCHEMISTRY OF METHANOGENESIS

Principal Investigators: Peck and Ljungdahl

\begin{abstract}
Several stable mesophilic fermentations of cellulose and wood to methane have been established and partially studied. A cellulolytic bacterium and sulfate reducing bacteria have been isolated and a highly enriched culture of an organism forming methane from acetate obtained. Levels of formyltetrahydrofolate synthetase and methylenetetrahydrofolate dehydrogenase have been investigated in various species of methanogenic bacteria and the evidence indicates that these enzymes are not involved in methane formation. However, both of these enzymes plus formate dehydrogenase and methenyltetrahydrofolate cyclohydrolase appear to be involved in the formation of acetate from $\mathrm{CO}_{2}$ and $\mathrm{H}_{2}$ by the "Balch" isolate, a new physiological type pf autotrophic anaerobe. The formate dehydrogenase of Clostridium thermoaceticum was shown to contain tungsten in its "active site" and this is the first report of a biological role for this metal. Attempts to demonstrate oxidative phosphorylation in methanogenic bacteria utilizing the hydrogenase/fumarate reductase couple, found to be widely distributed in these bacteria, have been inconclusive. A cytochrome $b$ has been detected in membrane preparations of $\underline{M}$. thernoautotrophicum grown in the presence of hemin and strongly suggests the presence of a membranebound electron transfer chain. This is the first report of a cytochrome in methanogenic bacteria and suggests the pxesence of a membrane-bound electron transfer chain.
\end{abstract}


Personnel:

Harry D. Peck, Jr., Head and Professor of Biochemistry

Lars G. Ljungdahl, Professor of Biochemistry

James G. Ferry, Research Associate and Postdoctoral Fellow of the National Institutes of Health - (Dr. Peck) Bioenergetics of methanogenesis; Methane cellulose fexmentation

David Sherod, Research Associate and Postdoctoral Fellow of the National Institutes of Health (Fellowship terminated 10/30/75) (Dr. Ljungdahi) Folate enzymology and microbiology of cellulosemethane fermentation

Gregory Dilworth, Research Associate and Postdoctoral Fellow of the National Science Foundation-Energy Related - (Dr. Peck) Isolation of electron transfer proteins from methane bacteria

Clyde Taylor, Research Assistant - Maintenance of cellulose fermentations and isolates

Gregory Shackleford, Research Assistant - Enzymology of folate enzymes and formate dehydrogeanse

\section{Publications:}

Ljungdahl, L. G., Tungsten, a biologically active metal, Trends in Biochemical Sciences 1:63-65'(1976).

Ljungdahl, L. G. and J. R. Andreesen, Tungsten, a component of active formate dehydrogenase from Clostridium thermoaceticum, FEBS Lett. 54: 279-282 (1976).

Ljunglahl, L. G. and J. R. Andreesen, Reduction of $\mathrm{CO}_{2}$ to acetate in homoacetate fermenting Clostridia and the involvement of tungsten in formate dehydrogenase, Symposium on Microbial Production and Utilization of Gases (Ed., H. Schlegel) 1976 (in press).

Ferry, J. G., D. W. Sherod, H. D. Peck, Jr. and L. G. Ljungdahl, Levels of formyltetrahydrofolate synthetase and methylenetetrahydrofolate dehydrogenase in methanogenic bacteria, Symposium on Microbial Production and Utilization of Gases (Ed., H. Schlegel) 1976 (in press).

\section{Presented Papers:}

Ljungdahl, L. G., Reduction of $\mathrm{CO}_{2}$ to acetate in homoacetate fermenting Clostridia and the involvement of tungsten in formate dehydrogenase, Symposium on the Microbial Production and Utilization of Gases, Gottingen, W. Germany.

Ferry, J. G., Levels of formyltetrahydrofolate synthetase and methylenetetrahydrofolate dehydrogenase in methanogenic bacteria, symposium on the Microbial Production and Utilization of Gases, Gottingen, w. Germany . 


\section{Manuscripts in Preparation:}

Ferry, J. G. and H. D. Peck, Jr., The distribution of fumarate reductase in methanogenic bacteria.

Ferry, J. G. and H. D. Peck, Jx., The presence of a cytochrome b in extracts of hemin grown $\underline{M}$. thermoautotrophicum.

Ljungdahl, L. G., R. S. Wolfe and R. Tanner, The pathway of acetate formation from $\mathrm{H}_{2}$ and $\mathrm{CO}_{2}$ in the "Balch" isolate. 


\section{PROGRESS REPORT: BIOCHEMISTRY OF METHANOGENESIS}

Principal Investigators: Peck and Ljungdahl

Introduction: Research in three areas of high interest and relevance has been initiated and will be continued in our laboratories. The first project is the microbial and physiological analysis of a mesophilic natural cellulose or wood fermentation with samples provided by Dr. Brown's group. The goal of this research is to identify intermediates in this complex fermentation, evaluate the roles of $\mathrm{CO}_{2}$ and acetate as substrates for methane formation and to establish the microorganisms essential for this complex food chain. This is supervised by both Drs. Ljungdahl and Peck. The second area of research concerns the pathways of methane and acetate formation from carbon dioxide and hydrogen and especially the production of methane from acetate as well as the biochemistry and physiology of bacteria capable of degrading celiulose. The emphasis of this project is directed towards the mechanism of enzymes known to be involved in $C_{1}$-metabolism, i.e. formate dehydrogenase and the folate enzymes. It is proposed also to biochemically characterize pure cultures of bacteria capable of fermenting cellulose, and the emphasis here is the evaluation of products and the stoichiometry as well as a more thorough investigation of the enzyme cellulase which is the initiator enzyme of the cellulase fermentation. This is primarily the responsibility of Dr. Ljungdahl. The third area of research concerns the bioenergetics of methane formation and is under the direction of Dx. Peck. "Attempts have been made to demonstrate the presence of an electron transfer chain, to identify its components and to show the presence of phosphorylation or active transport coupled to electron transfer. When available, it is anticipated that 
microorganisms isolated from the cellulose-methane fermentation will be utilized in the various research areas.

1. Bacteriological Analysis and Physiological Studies on the MethaneCellulose Fermentation

Mesophilic methane-cellulose fermentations have been established using both sycamore wood and sweet gum wood obtained from Dr. Brown, University of Georgia, as well as commercially available cellulose. All enrichments were initiated by adding a $10 \%$ inoculum of sediment from a fresh water pond, in which methane formation was evident, to a mineral salts medium which contained 1\% wood or cellulose as the sole energy source. Controls without cellulose or wood were inoculated simultaneously but never showed significant methane formation. Cultures were incubated anaerobically at $30^{\circ} \mathrm{C}$ and methane formation monitored by gas chromatography plus changes in pH values. Cultures were initially shaken but shaking proved to inhibit the establishment of a microbial population capable of producing methane from cellulose. With established methane producing cultures, shaking reduced the rates of methane formation and it has not been determined whether this represents problems with incomplete anaeroboisis, i.e. increased diffusion of trace amounts of $\mathrm{O}_{2}$ into the medium, or disxuption of a possible association of the cellulose-degrading bacteria with cellulose itself. Stationary cultures begin to evolve methane in 20-60 days, depending on conditions, and have been maintained for eight months by replacing $20 \%$ of the spent medium with fresh mineral-salts medium and adding 1\% wood or cellulose when methane formation ceases. Even with these crude systems, $50 \%$ of the theoretical amount of methane from cellulose is realized. As ten different enrichments have been established and maintained with essentially identical 
results, it appears to be a stable microbial population which will be amenable to microbiological and biochemical study.

Before methane production begins in the enrichment culture, the $\mathrm{pH}$ decreases from 7.0 to 4.0 (cellulose) -5.0 (wood) and rises again to 7.0 when methane production begins. This suggests that organic acids are the precursors of methane and that several organisms are required for the conversion (25). The analysis of these acids is in progress but they have not as yet been identified. Anaerobic microorganisms of four physiological types, i.e. cellulolytic bacteria, sulfate reducing bacteria, $\mathrm{CO}_{2}$-methanogenic bacteria and acetate-methanogenic bacteria, are being or have been isolated from these enrichment cultures employing the Hungate technique (10) for the isolation of strict anaerobes. A cellulnlytic bacterium has been obtained in pure culture utilizing the clearing of cellulose (10) agar as the screening technique and it is currently being characterized. It is a short rod which now clears cellulose agar in two-three days although it required 30 days in initial isolations. Sulfate-reducing bacteria are present at concentrations of $10^{4}$ to $10^{5} / \mathrm{ml}$ in these enrichment cultures and two isolations have been accomplished. Each strain utilizes lactate, ethanol, formate and fumarate as substrates for growth and have biocheminal characteristics similar to other known species of sulfate reducing bacteria (20) $\mathrm{CO}_{2}$-methanogenic bacteria have not yet been isolated in pure culture; however, a highly enriched culture has been obtained which converts acetate to methane at rates comparable to that observed in sewage sludge. Although acetate has been shown to be the major substrate for methane formation from cellulose (up to $70 \%$ of the methane formed) in anaerobic fresh water environments $(6,7,22)$, this important physiological type has never been isolated in pure culture. The final isolation and biochemical characterization of this microorganism should allow attempts. 
to reconstitute the entire food chain which converts cellulose to methane.

Discussion: The laboratory now has stable mesophilic methane-cellulose fermentations and the techniques for maintaining, monitoring and analyzing the fermentation have been established. Selected microbial types believed to be involved in the bioconversion have or are being isolated from these cultures and characterized.

2. The Role of Folate Enzymes in Methanobacterium thermoautotrophicum and the Pathway of Methane Formation

\section{A. Pathway of Methane Formation}

Initial considerations suggested that the tetrahydrofolate pathway might be involved in the formation of methane in methanogenic bacteria. Thus a goal of this project was to more precisely determine the physiological role of this pathway in the metabolism of methanogenic bacteria. In particular, high levels of two of the enzymes in this pathway had been preliminarily assayed in extracts from Methanobacterium thermoautotrophicum. After more detailed analysis these high levels of activity could not be repeated in freshly grown cells of M. thermoautotrophicum. In fact the high levels of activity were present only in one batch of frozen cells obtained from Dr. R. S. Wolfe (University of Illinois, Urbana). Since there were several new species of methanogenic bacteria recently isolated we were prompted to assay the levels of the tetrahydrofolate enzymes in these species to further assess the importance of the tetrahydrofolate pathway in methanogenic bacteria. Table 1 contains a summary of the levels of formyltetrahydrofolate synthetase and methylenetetrahydrofolate dehydrogenase observed in the various species of methane producing bacteria. The high values for specific activities of 
Table 1. Levels of formyltetrahydrofolate (formy $\mathrm{H}_{4}$-folate synthetase and methylenetetrahydrofolate (methylene $\mathrm{H}_{4}$-folate) dehydrogenase with $\mathrm{NAD}^{+}$or $\mathrm{NADP}^{+}$and electron acceptor. A unit of activity is defined as umoles of product formed per minute per millïgram of crude cell-free extract protein. Values reported in brackets are values obtained with cells grown in our laboratory.

\begin{tabular}{|c|c|c|c|}
\hline Organism & $\begin{array}{c}\text { Formy } \mathrm{H}_{4} \text {-folate } \\
\text { synthetase }\end{array}$ & $\begin{array}{c}\text { Methylene } \mathrm{H}_{4} \text {-folate } \\
\text { dehydrogenase } \\
\text { with } \mathrm{NAD}^{+}\end{array}$ & $\begin{array}{c}\text { Methylene } \mathrm{H}_{4} \text {-folate } \\
\text { dehydrogenase } \\
\text { with } \mathrm{NADP}^{+}\end{array}$ \\
\hline . & Units & Units & Units \\
\hline M. arbophilicum & 0.041 & 0.000 & 0.002 \\
\hline M. barkerii & 0.002 & 0.005 & 0.000 \\
\hline Methanosarcina UBS & 0.003 & 0.011 & 0.000 \\
\hline M. hungatii & 0.018 & 0.000 & 0.013 \\
\hline M. thermoautotrophicum & $3.3(0.05)$ & 0.000 & $0.980 \quad(0.06)$ \\
\hline
\end{tabular}


M. thermoautotrophicum reported in Table 1 were repeatedly observed in several extracts prepared with the frozen cells from Urbana. However, subsequent batches of fresh cells grown in our laboratory contained greatly reduced activities, of both enzymes. The lower activities observed were not due to inhibitors since no loss of enzyme activities were observed in Clostridium thermoaceticum extracts on addition of extract from the methanogenic organism to the reaction mixture.

Methylenetetrahydrofolate dehydrogenase of $\underline{M}$. thexmoautotrophicum, M. arbophilicum and $\underline{\text { M. hungatii }}$ was shown to be specific for NADP ${ }^{+}$. Methylenetetrahydrofolate dehydrogenase of $\underline{M}$. barkerii, Methanosarcina strain UBS and $\underline{M}$. formicicum were demonstrated to be $\mathrm{NAD}^{+}$specific.

If formyltetrahydrofolate synthetase and methylenetetrahydrofolate dehydrogenase were involved in a major metabolic pathway it would be expected that the levels of these enzymes would compare with the levels observed in Clostridium thermoaceticum (1) and Clostridium formicoaceticum (17). The low levels observed in all species are similar to the levels observed in other organisms utilizing these enzymes in C-1 synthesis (15). The evidence suggests that the methanogenic bacteria do not contain a major tetrahydrofolate pathway involving formyltetrahydrofolate synthetase or dehydrogenase. Minor pathways may function in the methanogenic bacteria which utilize low levels of these enzymes.

The frozen cells of $\underline{M}$. thermoautotrophicum supplied from Urbana were inspected microscopically and determined pure'. Enzyme assays with extracts prepared from these cells have been repeated many times and conditions for the assay studied in detail. The low activity observed in cells grown in our laboratory is puzzling. Initial attempts to determine the reasons for this variability have not been successful but experiments are continuing. 
It is of interest that in several of the methanogenic bacteria methylenetetrahydrofolate dehydrogenase is $\mathrm{NAD}^{+}$specific. This enzyme is generally found to be $\mathrm{NADP}^{+}$specific. Previously, NAD ${ }^{+}$specific methylenetetrahydrofolate dehydrogenase has been found only in Ehrlich Ascites tumor cells and in $\mathrm{C}$. formicoaceticum (15).

A preprint by Ferry, J. G., Sherod, D. W., Peck, H. D. and Ljungdahl, L. G. to be published as a Symposium paper in "Microbial Production and Utilization of Gases $\left(\mathrm{H}_{2}, \mathrm{CH}_{4}, \mathrm{CO}\right) "$ is enclosed with this application. This preprint covers in detail the determinations of tetrahydrofolate enzymes in methanogenic bacteria.

\section{B. Purification and Properties of Formate Dehydrogenase}

Formate dehydrogenase is the first enzyme in the formation of both methane and acetate from $\mathrm{CO}_{2}$ in methanogenic and acetate-forming bacteria. The purification of a formate dehydrogenase has not yet been achieved from an anaerobic bacterium. The enzyme is extremely oxygen sensitive and is thus rapïlly inactivated unless a stxict anaerobic environment is maintained during its isolation. It is also apparent that formate dehydrogenase from different types of bacteria use different natural electron acceptors or donors. Thus formate dehydrogenases exist which use ferredoxin, NAD, NADP, ubiquinones, cytochromes, oxygen and nitrate.

In 1973 Andreesen, in Dx. Ljungdahl's laboratorium, discovered that the formation of formate dehydrogenase in $\mathrm{C}$. thermoaceticum requires selenium and molybdenum or tungsten ( 1 ). It was subsequently shown that radioactive selenium and tungsten are incorporated into the enzyme (2). This was to our knowledge the first finding of a biological role for tungsten $(14$, reprint enclosed). During the last year anaerobic methods have been developed to 
isolate the formate dehydrogenase from $\underline{C}$. thermoaceticum. Using these methods a 50-fold purification has been achieved, and using radioactive tungsten it has been possible to postulate that the enzyme contains $1 \mathrm{~g}$ at W per mole of enzyme. The molecular weight of the enzyme is about 300,000 daltons. The enzyme is specific for NADP and is inactive with other possible natural electron acceptors. Although the enzyme has been purified 50-fold, it is still not pure and with gel electrophoresis it has been shown that the preparations contain 4 proteins.

Presently attempts are being made to scale up the procedure for purification so that we will be able to isolate mg quantities of the enzyme and to purify it to homogeneity. The procedure followed is to include formate as substrate and methyl viologen as electron accepor in the solution used in the purification. Methyl viologen in reduced form is blue and the formation of the blue color is an excellent indicator of the presence of the enzyme. Reduced methyl viologen is also rapidly oxidized to tis colorless form by oxygen. Thus, a stable blue color indicates anaerobic conditions so necessary for isolation of the formate dehydrogenase. The semi-purified enzyme can be stored anaerobically for at least 14 days without loss of activity. Thus, we have high hopes to be able to obtain pure enzyme in the near future.

\section{Formation of Acetate from $\mathrm{CO}_{2}$}

Acetate is formed from $\mathrm{CO}_{2}$ in two types of reductions. The first type occurs in the homoacetate fermenting Clostridia which ferment/mole of glucose or fructose to 3 moles of acetate as follows:

(1) $\mathrm{C}_{6} \mathrm{H}_{12} \mathrm{O}_{6}+\mathrm{H}_{2} \mathrm{O} \rightarrow \mathrm{CH}_{3} \mathrm{COCOOH}+\mathrm{CH}_{3} \mathrm{COOH}+\mathrm{CO}_{2}+6 \mathrm{H}$ 
(2) $\mathrm{CH}_{3} \mathrm{COCOOH}+\mathrm{CO}_{2}+6 \mathrm{H} \rightarrow 2 \mathrm{CH}_{2} \mathrm{COOH}+\mathrm{H}_{2} \mathrm{O}$

(3) ${ }_{1}{ }_{6} \mathrm{H}_{12} \mathrm{O}_{6} \rightarrow 3 \mathrm{CH}_{3} \mathrm{COOH}$

According to reaction 2 carbon dioxide is reduced by electrons formed in reaction $I$ to the methyl group of acetate. The pathway of this reduction has been extensively investigated in H. G. Wood's and our laboratory using Clostridium thermoaceticum (15) and Clostridium formicoaceticum (17).

The second type was discovered several years ago by Wieringa (24) who found an organism named Clostridium aceticum which had the capacity to reduce $\mathrm{CO}_{2}$ with molecular hydrogen to form acetate. Unfortunately this organism was lost. However, recently in Dr. Wolfe's laboratory in Urbana, Illinois, a new microorganism was isolated by Schoberth and Balch (21). This organism like $\underline{C}$. aceticum is able to reduce $\mathrm{CO}_{2}$ with $\mathrm{H}_{2}$ to form acetate. In cooperation with R. Tanner in Dr. Wolfe's laboratory, we have investigated the pathway for synthesis of acetate in the new "Balch" isolate.

The pathway in $\underline{c}$. thermoaceticum and $\underline{c}$. formicoaceticum involves the reduction of $\mathrm{CO}_{2}$ to formate, which is further metabolized and reduced to methyltetrahydrofolate via tetrahydrofolate enzymes. The methyl group of methyltetrahydrofolate is then in a not completely understood reaction converted to acetate through transcarboxylation involving the carboxyl-group of pyruvate. The enzymes involved in the acetate synthesis are present in large amounts in the two homoacetate fermenting clostridia, indicating that they are involved in a major pathway.

The level of these enzymes have now been determined in the "Balch" isolate and they are all present in large amounts as shown in the following table (Table 2). The enzymes were assayed according to methods described by O'Brien and Ljungdahl (17). 
Table 2. Level of enzyme involved in acetate synthesis from $\mathrm{CO}_{2}$ in the "Balch" isolate. Figures are umoles of product formed per minute per $\mathrm{mg}$ of protein in crude French press extracts.

\begin{tabular}{ll}
\hline \multicolumn{1}{c}{ Enzyme } & $\mu$ umoles $\mathrm{min}^{-1} \mathrm{mg}^{-1}$ \\
\hline Formate dehydrogenase & \\
Formy $1-\mathrm{H}_{4}-$ folate synthetase & 0.15 \\
Metheny $1-\mathrm{H}_{4}$-folate cyclohydrolase & $8.78-13.54$ \\
Methylene- $\mathrm{H}_{4}$-folate dehydrogenase & $0.125-0.699$ \\
\hline
\end{tabular}

With methyl viologen as electron acceptor.

$b_{\text {With }} \mathrm{NAD}^{+}$as electron acceptur.

The levels of enzymes in the "Balch" isolate are comparable with those found in the two homoacetate fermenting Clostxidia (17). These results indicate that the "Balch" isolate forms acetate from $\mathrm{CO}_{2}$ by a pathway similar to the homoacetate fermenting Clostridia.

However, there are some differences; thus, the formate dehydrogenase in the "Balch" isolate is different from that of Clostridium thermoaceticum. The "Balch" isolate enzyme does not use NADP or NAD as electron acceptor, and the natural acceptor is still unknown. Furthermore, the methylenetetrahydrofolate dehydrogenase in the "Balch" isolate is NAD-specific and is thus different from the enzyme of $\underline{C}$. thermoaceticum which is NADP-specific. The $\underline{C}$. formicoaceticum enzyme is NAD-specific and is similar to that of the "Balch" isolate; however, the "Balch" isolate enzyme requires magnesium ions for maximum activity, a requirement not found for the $\underline{C}$. formicoaceticum enzyme. 
That the "Balch" isolate uses the same pathway for acetate synthesis from $\mathrm{CO}_{2}$ as the homoacetate fermenting Clostridia is further substantiated by the finding that methyltetrahydrofolate and methyl cobalamin are substrate for acetate with the "Balch" isolate. This is shown in Table 3.

Table 3. Formation of acetate from methyltetrahydrofolate and methyl cobalamin by extracts of the "Balch" isolatea

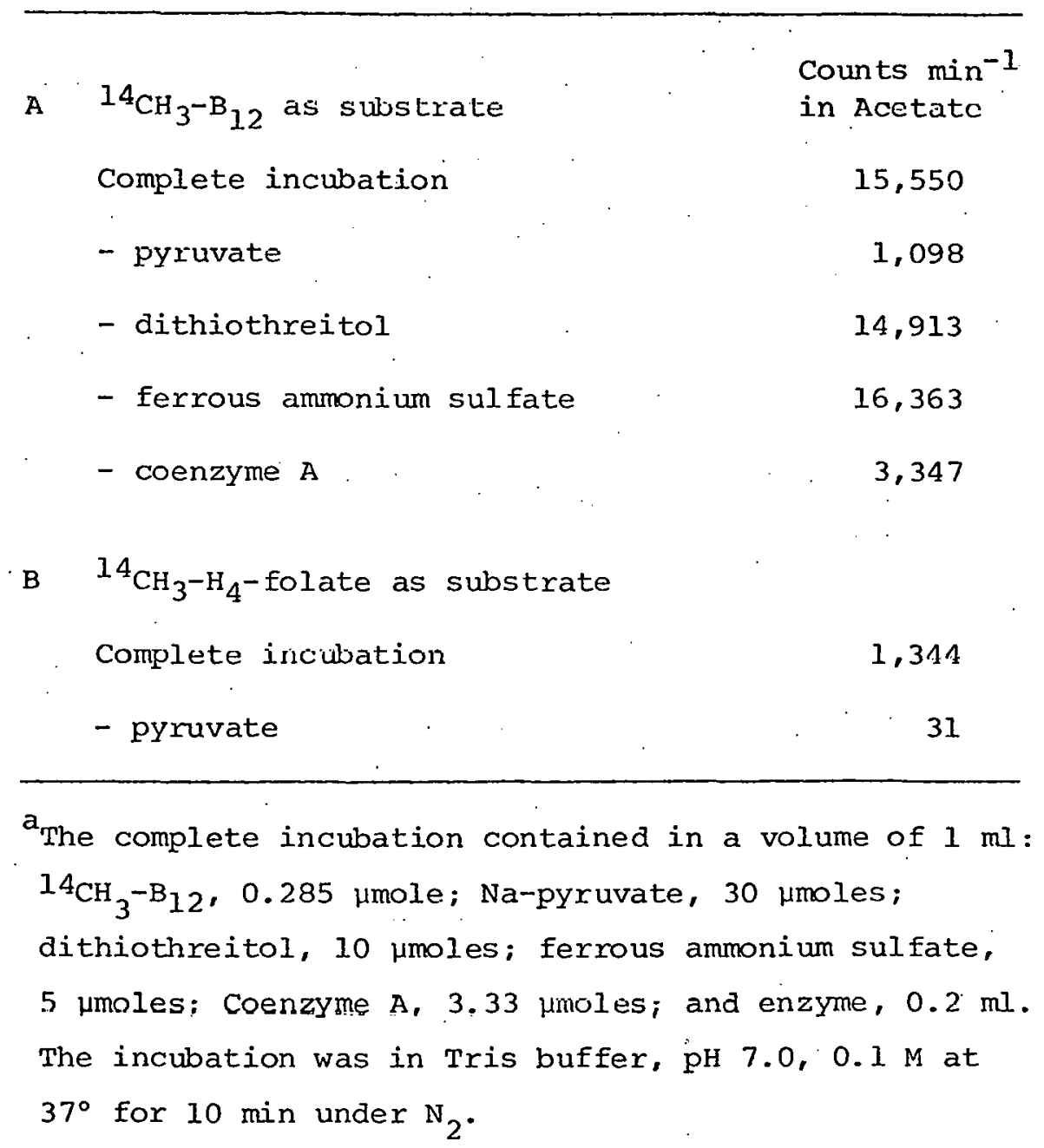

As may be noticed the formation of acetate from the two radioactive substrate is completely dependent on pyruvate, a finding which is congruent with what has been found in $\underline{C}$. thermoaceticum and $\underline{C}$. formicoaceticum. 
The content of corrinoids (vitamin $\mathrm{B}_{12}$-derivatives) was also determined in the "Balch" isolate and was found to be about 50 umoles of corrinoids per $100 \mathrm{~g}$ of wet cell paste. This amount is in excellent agreement with what is found in $\mathrm{C}$. thermoaceticum (between 30-90 $\mu$ moles per $100 \mathrm{~g}$ wet cell paste). As with $\underline{C}$. thermoaceticum the presence of cobalamin containing proteins in the "Balch" isolate has also been demonstrated.

The above result strongly indicate a pathway for the synthesis of acetate from $\mathrm{CO}_{2}$ in the "Balch" isolate similax to that in $\underline{\mathrm{C}}$. thermoaceticum and $\underline{C}$. formicoaceticum. This is the first instance where autotrophic $\mathrm{CO}_{2}$ fixation has been shown to process through a mechanism other than the Calvin cycle.

\section{Electron-Transfer Coupled Phosphorylation and the Electron-Transfer Chain}

Project: The overall reaction for the reduction of $\mathrm{CO}_{2}$ to $\mathrm{CH}_{4}$ with $\mathrm{H}_{2}$, i.e. $4 \mathrm{H}_{2}+\mathrm{CO}_{2} \rightarrow \mathrm{CH}_{4}+2 \mathrm{H}_{2} \mathrm{O}$, indicates that $\mathrm{CO}_{2}$-methanogenic bacteria must generate ATP for growth by means of an anaerobic oxidative phosphorylation. There is ro direct evidence for this process (25) and it was proposed to obtain such a system in cell-free extracts and to study the system with regard to its control and electron transfer carriers much as has been done with the sulfate-reducing bacteria $(3,18,19)$.

Results: As the pathway for $\mathrm{CO}_{2}$ reduction to methane is unknown, the first problem was to select an electron donor/acceptor system for these studies. All of the methanogenic bacteria-which have been examined contain good hydrogenase activity (25) and this allows $\mathrm{H}_{2}$ to be utilized as the electron donor for these studies. $\mathrm{H}_{2}$ is the physiological electron donor for methane 
formation and in the sulfate-reducing bacteria, it is located in the periplasmic space where it has been postulated to function in interspecies $\mathrm{H}_{2}$ transfer $(4)$. The possible periplasmic location of hydrogenase of $\mathrm{M}$. thermoautotrophicum was investigated by the preparation of spheroplasts and osomotic shock and the results (Table 1) clearly indicated that hydrogenase

Table 1. Intraceliular location of hydrogens of $\underline{M}$. thermoautotrophicum

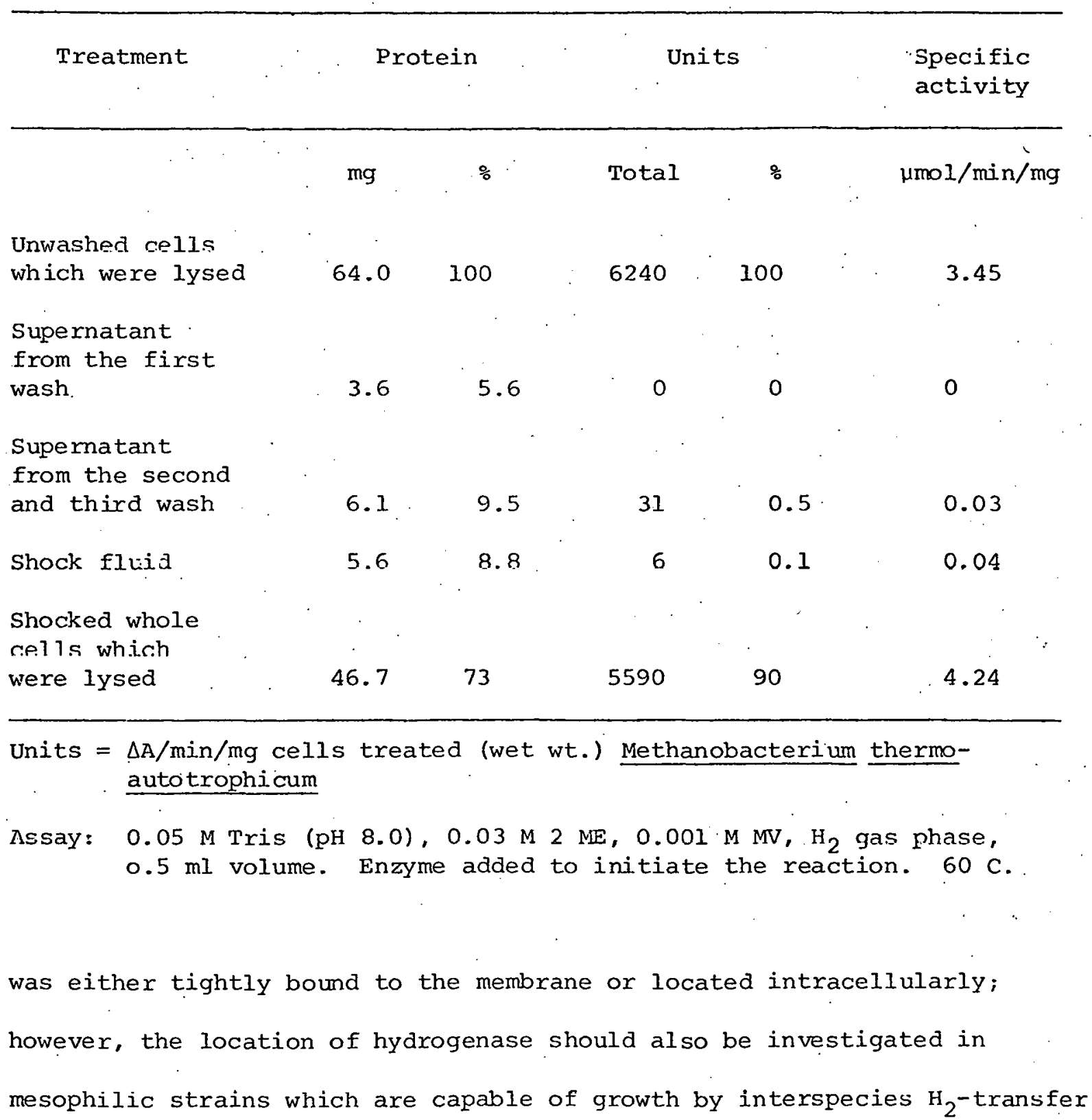


Fumarate is widely used as a terminal electron acceptor by anaerobic bacteria (16) and it appeared that the problem of an electron acceptor system might be solved by a fumarate/fumarate reductase system. As shown in Table 2, the hydrogenase/fumarate reductase system was found in all the

Table 2. Fumarate reductase activity in several species of methanogenic bacteria. Values are reported as $\mu$ mol $\mathrm{H}_{2}$ utilized per hour per mg protein. MV is methyl viologen.

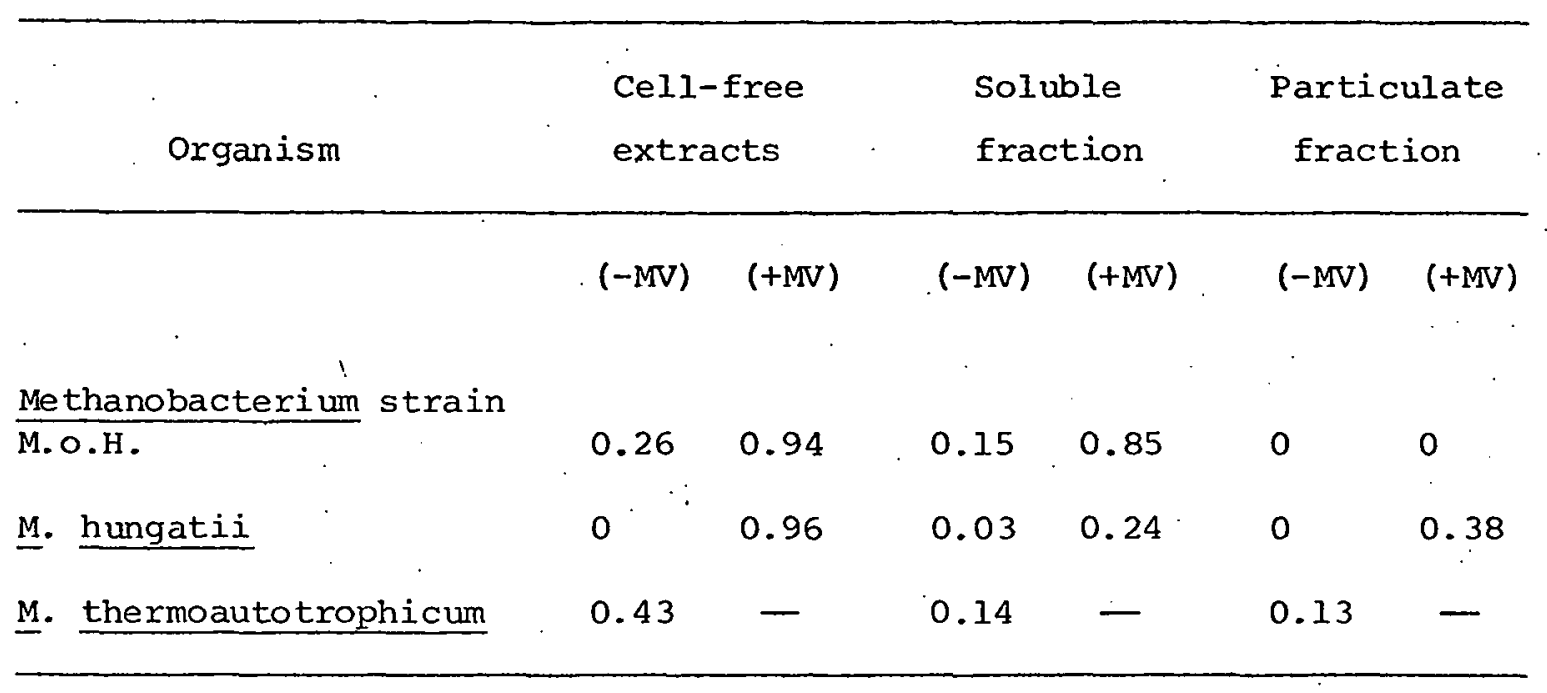

methanogenic bacteria investigated (also found in $\underline{M}$. formicicium and $\underline{M}$. barkerii); however, the properties of the system were quite variable. In the case of Methanobacterium strain M.o.H., the enzymes were completely soluble and stimulated by the addition of methyl viologen, while with M. hungatii the enzyme system was both soluble and particulate but required the presence of methyl viologen. M. the rmoautotrophicum was the only organism that contained activity. in the particulate fraction without. methyl viologen (an uncouplex of anaerobic oxidative phosphorylation); however, due to technical problems associated with the thermophilic nature of the system and the low level of activity, initial attempts to demonstrate 
phosphorylation coupled with hydrogen oxidation and fumarate reduction in particles of this organism were not conclusive. In an effort to increase the activity of the hydrogenase/fumarate system, $\underline{M}$. the rmoautotrophicum was grown under a number of nutritional conditions. It has recently been found that the presence of hemin in the medium elevates the level of this activity and the particles exhibit a typical cytochrome spectrum. By means of the Amino-Chance spectrophotometer, reduced minus oxidized difference spectra at liquid nitrogen temperatures indicated a b-type cytochrome ( $\alpha$ peak at $558 \mathrm{~nm} ; \beta$ peak at $528 \mathrm{~nm}$; Soret at $428 \mathrm{~nm}$ ). This constitutes the first evidence of cytochromes in methanogenic bacteria and suggests the presence of a cytochrome containing electron transfer chain in these membrane fragments.

Our laboratory has been highly successful in isolating low molecular weight electron transfer proteins and enzymes from the sulfate reducing bacteria and at least four of these have proved to be biochemically unique proteins $(5,11,12,23)$. The basic idea has been to start with kilogram amounts of bacteria and obtain pure proteins without initially being concerned with yields and enzyme activity. This approach is possible as the Department of Biochemistry maintains a formentation plant with two $400-1 i t e r$ fermentors and it was proposed to apply this approach to the methanogenic bacteria. Due to lack of personnel, only preliminary experiments were accomplished, but these proved to be very interesting and promising. Extracts appear to be completely different from those of other strict anaerobes which have been examined. The unique low molecular weight (8) cofactor $\mathrm{F}_{420}$ was easily identified but it was not possible to identify flavodoxin, ferredoxin, or rubredoxin and, in contrast to most strict. anaerobes, there was little free flavin and flavoprotein. These 
differences are very striking and suggest that this approach to the bioenergetics and energy metabolism of methanogenic bacteria should provide new and basic information.

Discussion: The presence of fumarate reductase in extracts of the methanogenic bacteria is interesting because of the limited substrate potential of intact cells and the lack of enzymological data available from extracts of pure cultures. Its presence suggest that the methanogenic bacteria may be able to grow utilizing fumarate respiration to generate energy. Although oxidative phosphorylation has not as yet been conclusively demonstrated in this group of anaerobes, the general approach appears to be promising as the hydrogenase/fumarate reductase system is present in all organisms examined. It now appears to be only a matter of defining the proper conditions or species of organism. 'the presence of a cytochrome in the methanogenic bacteria has been demonstrated for the first time and suggests the presence of an electron transfer chain; however; the induction of cytochrome formation by hemin has been observed in a number of anaerobic bacteria (16) and hemin is required for the growth of a number of Bacteroides (9). The methanogenic bacteria appear to be unique anaerobic bacteria about which little is known and investigation of their bioenergetics, physiology and biochemistry promises to be most rewarding. 


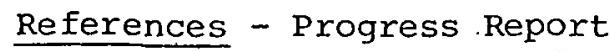

1. Andreesen, J. R., Schaupp, A., Neurauter, C., Brown, A. and LjungdahI, L. G. 1973. Fermentation of glucose, fructose, and xylose by Clostridium thermoaceticum: Effect of metals on growth yield, enzymes and the synthesis of acetate from $\mathrm{CO}_{2} \cdot \mathrm{J}$. Bact. 114: 743-751.

2. Andreesen, J. R. and Ljungdahl, L. G. 1973. Formate dehydrogenase of Clostridium thermoaceticum. Incorporation of selenium-75 and the effects of selenite, molybdate and tungstate on the enzyme. J. Bact. 116: 867-873.

3. Barton, L. L., LeGall, J. and Peck, Jr., H. D. 1970. Phosphorylation coupled to oxidation of hydrogen with fumarate in extracts of the sulfate-reducing bacterium Desulfovibrio gigas. Biochem. Biophys. Res. Commun. 4l: 1036-1042.

4. Bell, G. R., JeGall, J. and Peck, Jr., H. D. 1974. Evidence for the periplasmic location of hydrogenase in Desulfovibrio gigas. J. Bact. 120: 994-997.

5. Bruschi, M., LeGall, J., Hatchikian, C. E. and Dubourdieu, M. 1970: Cristallisation et propriétes d'un cytochrome intervenant dans la réduction du thiosulfate par Desulfovibrio gigas. Bull. Soc. Fr. Fhysiol. Veget. 15: 381 .

6. Cappenberg, Th. E. 1974. Interrelations between sulfate-reducing and methane-producing bacteria in bottom deposits of a fresh-water lake.

I. Field Observations. Antonie van Leeuwenhoek 40: 285-295.

7. Cappenberg, Th. E. and Prins, R. A. 1974. Interrelations between sulfate-reducing and methane-producing bacteria in bottom deposits of a fresh-water lake. III. Experiments with ${ }^{14} \mathrm{C}$-labeled substances. Antonie van Leeuwenhoek 40: 457-469.

8. Cheeseman, P. A., Toms-Wood, A. and Wolfe, R. S. 1972. Isolation and properties of a fluorescent compound, factor 420 from Methanobacterium strain M.O.H. J. Bact. 112: 527-531.

9. Gibbons, R. J. and MacDonald, J. B. 1960. Hemin and vitamin $\mathrm{K}$ compound as required growth factors for the cultivation of certain strains of Bacgeroides melaninogenicus. J. Bact. 80: 164-170.

10. Hungate, R. E. 1966. The Rumen and Its Microbes. Academic Press, New York.

11. Lee, Jin-Po, LeGall, J. and Peck, Jr., H. D. 1973. Isolation of Assimilatory and dissimilatory type sulfite reductase from Desulfovibrio vulgaris. J. Bact. 115: 529-542. 
12. Lee, J.-P., Yi, C.-S., LeGall, J. and Peck, Jr., H. D. 1973. Isolation of a new pigment, Desulforubidin, from Desulfovibrio desulfuricans (Norway strain) and its role in sulfite reduction. J. Bact. 115: : $453-455$.

13. Ljungdahl, L. G. and Andreesen, J. R. 1975. Tungsten, a component of active formate dehydrogenase from Clostridium thermoaceticum.

FEBS Lett. 54: 279-282.

14. Ljungdahl, L. G. 1976. Tungsten, a biologically active metal. Trends in Biochem. Sciences 1 : 63-65.

15. Ljungdahl, L. G. and wood, H. G. 1964. Total synthesis of acetate from $\mathrm{CO}_{2}$ by heterotrophic bacteria. Annu. Rev. Microbiol. 23: 515538.

16. Macy, J., Probst, I. and Gollschalk, G. 1975. Evidence for cytochrome involvement in fumarate reduction and adenosine $5^{\prime}$-triphosphate synthes is by Bacteroides fragilis grown in the presence of hemin. J. Bact. 123: $436-442$.

17. O'Brien, W. E. and Ljungdahl, L. G. 1972. Fermentation of fructose and synthesis of acetate from carbon dioxide by Clostridium formicoaceticum. J. Bact. 109: 626-632.

18. Peck, H. D., Jr. 1960. Evidence for oxidative phosphorylation during the reduction of sulfate with hydrogen by Desulfovibrio desulfuricans. J. Biol. Chem. 235: 2734-2738.

19. Peck, H. D., Jx. 1966. Phosphorylation coupled with electron transfer in extracts of the sulfate reducing bacterium, Desulfovibrio gigas. Biochem. Biophys. Res. Commun. 22: 112-118.

20. Postgate, J. R. and Campbell, L. L. 1966. Classification of Desulfovibrio species; the non-sporulating sulfate-reducing bacteria. Bacteriol. Rev. 30: 732-738.

21. Schoberth, S. M. and Balch, w. E. 1975. A new hydrogen-oxidizing acetate-forming anaerobe. Abstr. Annu. Meet. Am. Soc. Microbiol. I 90 .

22. Smith, P. H. and Mah, R. A. 1966. Kinetics of acetate metabolism during sludge digestion. Appl. Microbiol. 14: 368-371.

23. Travis, J., Newman, D. J., LeGall; J. and Peck, Jr., H. D. 1971. The amino acid sequence of ferredoxin from the sulfate reducing bacterium, Desulfovibrio gigas. Biochem. Biophys. Res. Commun. 45: $452-458$.

24. Wiexinga, K. T. 1946. The formation of acetic acid from carbon dioxide and hydrogen by anaerobic spore-forming bacteria. Antonie van Leeuwenhoek J. Microbiol. Serol. 6 : 251-262. 
25. Wolfe, R. S. 1972. Microbial formation of methane. Adv. Microbiol. Physiol. 8 : $107-145$. 